ESTUDO BROMATOLÓGICO DE CONCENTRADOS PROTÉICOS DE SARDINELLA AURITA E DE TILÁPIA MELANOPLEURA OBTIDOS POR EXTRAÇÃO COM ISOPROPANOL

TESE APRESENTADA À FACULDADE DE FARMÁCIA E BIOQUIMICA DA UNIVERSIDADE DE SÃo PAULO PARA OBTENÇÃo do título de TTUTOR, 
Us nussos meliorss agradocimentos

Ao PROP。 MARTA IPPARECIOA FOURCHSX CAEPOS, pela orientagéa desta ters.

AO DR.JATO EATISTA DOMINGUES,

pelas oportunas sugestoas apresentadas.

Ao IR. SSROTO ZTCUES ZUWAS, pela ajuda ra realtragão dêste trabalho.

Ao $D R_{c}$ IUARI ISSKO e sun equipi. pola cooperaçáo prestada. 
2 - PROPOSTGKO0.0000000000000000000000000000000000000 I

2 - REVTSFOO DA LITERTATURA 0000000000000000000000003 $2 . I$. A OBTENCAO DOS CONCENTEADOS PFOTLTCOS.-

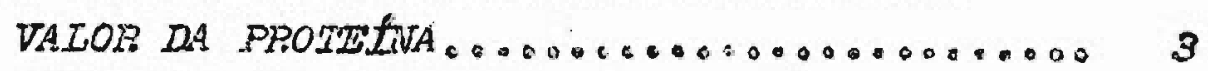

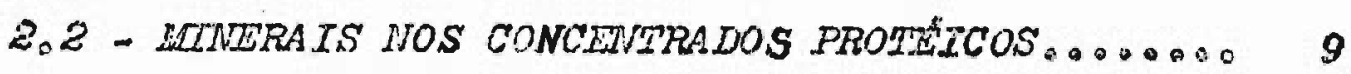

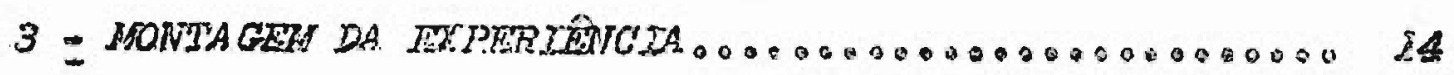

4 - MATERTAL ITILIZADO0000000000000000000000000000000 $\$ 6$

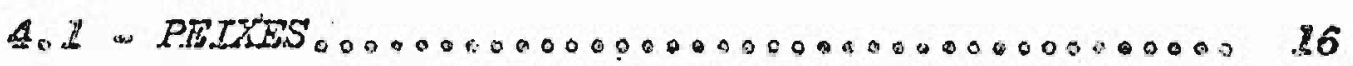

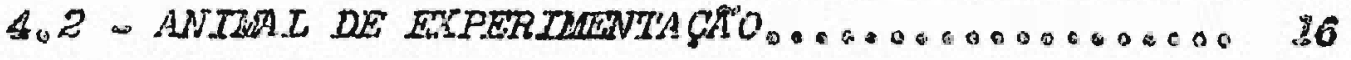

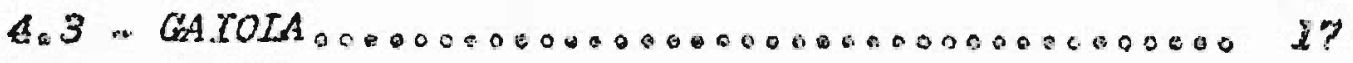

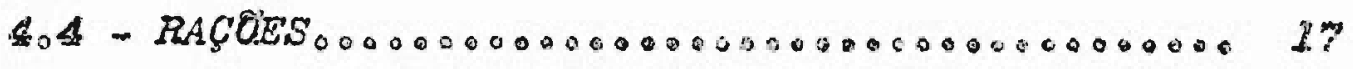

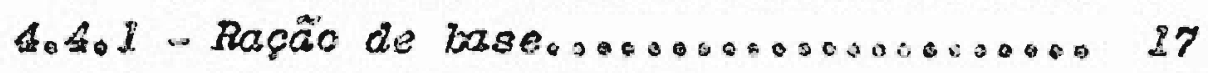

4.4.2 - Raçoês experimentais.00s0n000000000 IB

5 - METODOS00000000000000000000000000000000000000000 2I

5.1 PREPARO DOS COUCITITRADOS PROIEICOS.0000.000 21

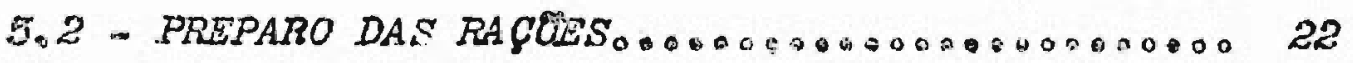

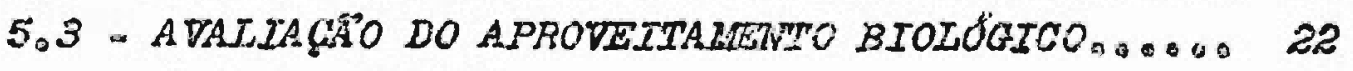

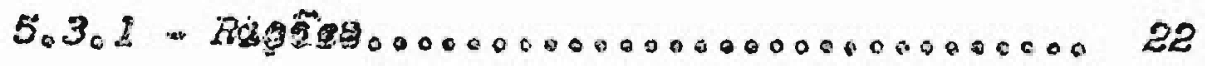

$503_{0} 2$ - Protelratanc00000000000000000000000 22

50303 - Litnetats,00000000000000000000000000 23

504 - ANALISE DA CARCAGA00000000000000000000000 23

5.4.I - Preparo do material zara anailisen. 23

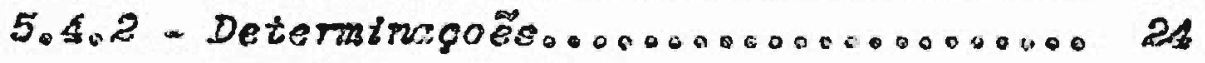

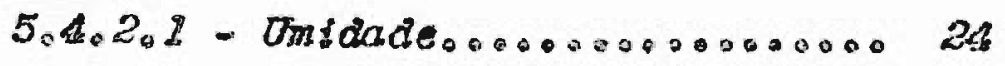

5.40 .202 - Exirato etéreo.0060000000 24

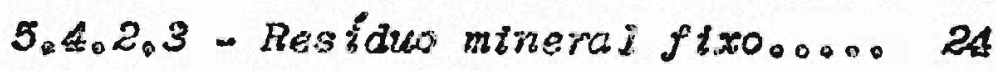

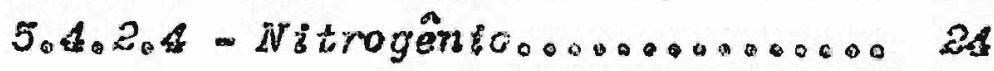

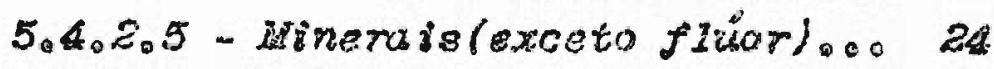

5.4 .2 .6 -Determbtração do flúor.oreo 24

$544.2_{0} \%$ - Deteminacäo doe

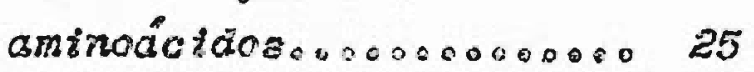




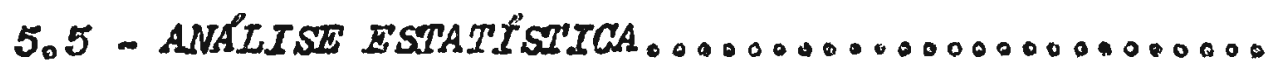

6 - DADOS ANLALITICOS, 000000000000000000000000026

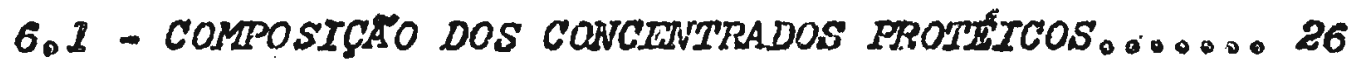

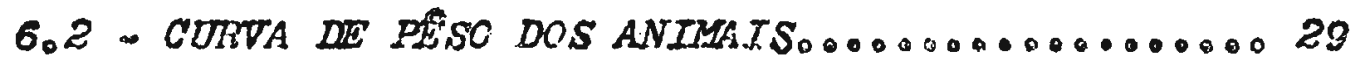

6.3 - COEFTCIENIE DE ETICÁCIA PROTELICA E

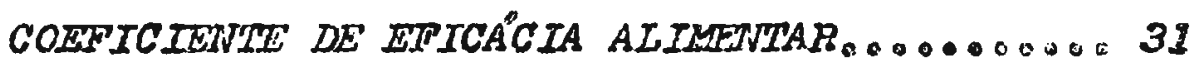

6.4 - RESULTADOS OBTIDOS PRIA

AIJALISER DAS CARCACASE

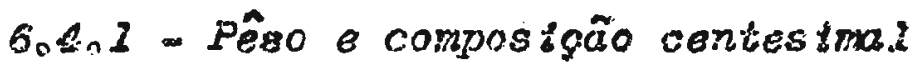

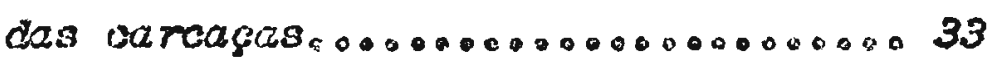

6.4.2 - Aproveitamenio perecniva.2 20 nttrogênto ingeridoco00000000000000035

6.403 - Aproveitamento percential do cilleso. do jósfore o do flicor ingertidos on a. 37

6.5 - TABELA CERALON00000000000000000000000000000 4 II

7 - ANALTSE DOS DADOS 0000000000000000000100000000000043

7. I - CONCENTRADOS FROMZITCOS, 0000000000.006000000443

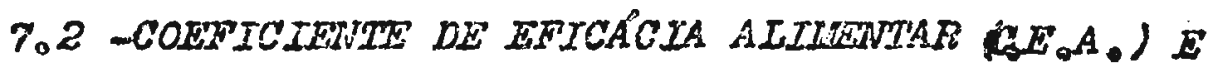

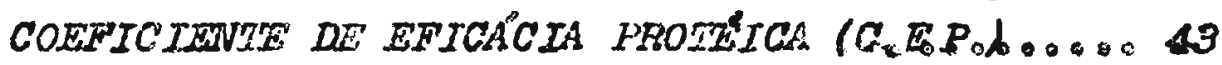

7.3 -APROVETTAUENTO PERCLTHUUAL DO NTTROCBNTO

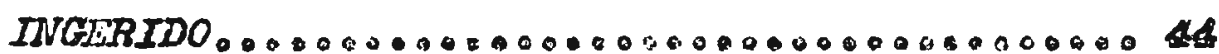

7.4 - APROVEITAMENITO PERCENTUAL DO GA'TCTO INGERIDO 4

7.5 - APROYEITANERTO PERCEIIUALL DO FÓ́LITORO

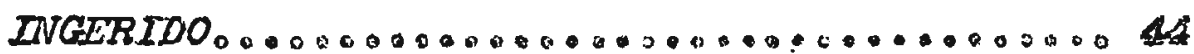

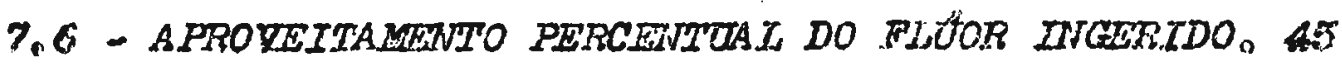

8. DISCUSSERO DOS RESULTADOS 00000000000000000000000 \$6

8.1 - OS CONCENTRADOSOODO00000000000000000000000 46

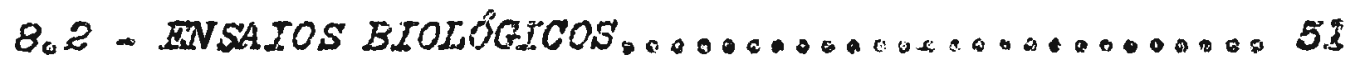

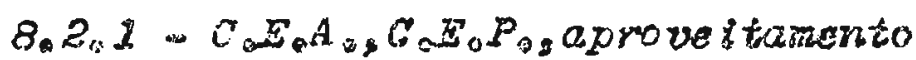
percentzal do nitrogêntoco0000000000 5L $B_{Q} 2_{0} Z$ - Aprovet tamento dos mineraligeoposoos 55

9 CONCLUSRES $0000000000000000000000000000000000006 E$

20. REFEREATCIAS RIELJOCTAFTCAS 


\section{1 - PROPOSTCGTO}

A disponiblidida de allmentos nos dias atuals e,principalment o quadro al imentar que enfrentaremo no futurax em consequênola da expansäo demográftca,fosen que o problema aIrmentar ec trunsforme em um doe desaflos maxtmos de nossa ipaoa, precteando ser encarado con dispostgäo por todos os que tîn responsablilidade na procura de solupote.

Na verdade, $\grave{a}$ medtda que as populaçor̈s awaen -

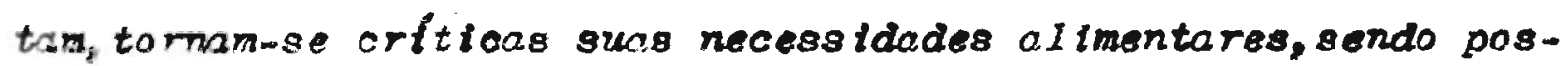
sivel dizer que estas, nas próxims décodas dificilmente poderäo ser atendidas pelos melos convenclonats da agrloultura eda peoucírta.

Dentro disso, un dos pontos mats sérios do btnômio populagão/produção de alimentos é o da defletêncía de pro telnas. Para a diminulģ̃o dêsse desequtlibrto, devemos saltentar a importâncla que assumem os peixes e pescadoso Infeltzmente,po rém, Irande parte dêsse potenctal tem sido despordiçada, en ra vão de sua fácil pereolbilidace e da falta de ractonal aprovettamento da matérta prima formocida pela naturesa.

Os concentrados protéloos de peixe, produstdos a partir de petxes intelros ou de restduos de sua industrialtsação, cferecem a vantagem de un elevado valor biológleo pelos aminoåcidos presentes, zen alto teor mineral, possibilidade do boa aceltação para consumo do homex batxo ousto operactonal.São, 
ainda, de fácil conservação, o que constitut importante fator pa. ra seu aproveitamento, principalmente em condicôes adversas de oltma.

Considerando a nossa extensão costetra, o gran de volune de nossas águas fluviais e as posstbilidades de expan. são das inchistrias da pesoa e da piscioultura, os petxes os pro dutos dêles dertuados assumem grande importânota como mananotal de alimentos de alto qualidade para o Brasilo

Assim, proourando oontributr para o conicet mento de nos8o potencial altwentar,propusano-nos cetudar o valor

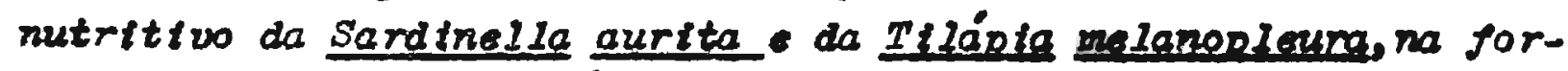
ma de concentrados protélcos obtidos por desidratagäo, desengorduramento e desodoriagão com tsopropanol.

o nosso trabalho fol orientado, mome primetra etapa, no sentido do determinar:

a) a composigão oentestmal, a composigâo mineral a de aminocieidos dos concentrados.

blo valor biológico da protefna do complexo protéloo-mineral dos concentrados。

Nina segunda etapa, procuramos avaliar o poten clal que ésese procutcs poderẫo representar no fomectmento do certos minerais para o organismo, ensatando, em ratos, o-aprovettamento do cálcto, do fösforo e do flior nêles presintes. 
2 - REVIITTO DA LITERATURA

2.1 - A obtenşão dos concentrados protéicos -

Valor da proteína

Fot a elevada potenctaltade dos mares, rios e lagos, como fonte de alimentos de alta qualidade, que estimilou estudios no senitdo do prodrşão e utilizagão do ooncentrados de peixes para a alinentaça do homeno

Jea sempre, porém, êstes apresentam as condifôes exigidas para consumo humano, razäo pela qual se pro. ourou estabeleoer normas para sua produsão e contrôle, com a ft nalidade de torná-10s compativels con o uso proposto. Tats produtos, dos quats a água e a gordura são retiradas, passa ram a ser denoninados "farinhas de peixe." e, mats recentemente, " concentrados protélicos de pelxe "permanecendo a denominagâo Lish meal, dos pafses de Ifngua inglêsa, para o produto destinado ao uso animal.

Bcistcamente, estabeleceram-se do ts tipos principats de concentrados protéicos de peixe $\mid F A O$ (18)|: tipo A, desengordurado e desodortado, destinado a populaçóes que não apreciam o odor do peixe (contendo no máxtmo 0 , Th, de liftdes); tipo $B$, que pode conter até 3 's de gordura, destinado a populaçôes hájtrudas a êsse gôsto e odor. No Brast1, devtdo aos hábitos tradiciona is de nossa população, jaroce-nos que o tipo A tería preferência. Releva, ainda, salientar que o tipo A não apresenta o inconventente da rancificagão, con o desen- 
volvimento de odores estranhos e formagão de compostos noctvos | KONING e MOMULEAN (35) OLCOTT (72) |.

A mator parte dos métodos utilitados pare a produção de concentrados protétcos tipo A baseta-se no emprêgo de solventes.

o processo usado pela "Vtobin", de Monticello (IIIinois), originalmente tdealizado por LEVIV (46), uti1tza o 1,2-dtcloraetano para a desidratagão e desengorduramento, sendo o metanol, etanol ou tsopropanol empregados para a desodo rizacão.

No Canodá foram desenvolvidos processos que empregam apenas isopropanol I COITMANN e VANDIGWHEUVLL (25), POWER (79)/: recentemente, fot aprovado, nos Estados Unidos, processo do "Bureau of Commercial Fisheries" de Maryland (99), que também utilisa êste solvente.

Em Quintero, no Chile, com o auxt1 to da UNICEF* , o concentrado obt $i d o$ do Merlucolus gaut é produztdo com misturas de hesano-etanol, ou apenas etanol, sendo o peixe prèviamente dessecado |YÁNEZ e col. (103)|. o etanol é também utilizado pelo FIRI (Fishing Industries Research Institute), na África do sul, para obter farinhas de sardinha, jurel e merluzza |DREOSTI (15)|. Em Agadir, no Llarrocos, com o auxil10 da FAO, inictou-se, ha algun tempo, a procucão de concentrados (princtpaI mente de sardinhas prèviamente cozidas e prensadasl por tratamen to com misturas de solventes como hesano, acetato de etila e isopropanol |KNOBL (34)|.

Como o produto é destinado a fornecer nutrientes de alta qualidade, o valor nutrictonal do tnsuno deve ser mantido. Os dados referentes ao valor biológtoo da protetna de diversos concentrados protétcos já ensatados indican que isso é posstuel.

Os concentrados protétcos obtidos pelo 1,2 - dicloroetano foram estudados por vários autores \&ALITA (56) encontrou, para os concentrados da "Viobtn", coeficientes de efica"cia protétca próximos a.os da protefna do ôvossCHENDEL e JOHV. SON (83) estudaram, comparativamente, os concentrados da "Viobin" e a caseína, como fontes protétcas na reproducão de ratos, até a quarta geracão. Encontraram melhores resultados para os con- 
centrados da "Vtobin".

JAFFIS (32) ensatou concentrado da mesma procedêncta, obtendo coefictente de eficácta protétca da mesna ordem que o da casefna. Por outro ladoso valor blológico da protéfna, medido pela uttlização protélca ltgtida revelou ser o concentrado ligetramente superior à caseína.

Bste autor veriftcou, cinda, que a adição de metionina elevava o valor biológico da protelna, evidenciando uma defictência dêsse aminoáctdo no produto. o concentrado. adicionado na proporcão de $20 \%$ a una racão contendo apenas $m i$ Iho amarelo moldo ("funcine"), sem suplemento vitamínico ou mi neral, fornecido a ratos através de duas gerações, näo mostrou toxicidade nem evidenctou deficiênctas alimentares quando compa rado a uma rasão comerctal (purina).

GOYCO e ASENJO (24) encontraram, para wo concentrado da mesma procedência, valores elevados relativamente ao coeficiente de eficácta protétca, bem como para o "indice de lactância" *a protétna.

Recentemente, MURNO e MORRISON (67) (68),

estudando a bioqufmica dos concentrados protétcos de flilés de Gadus morrhwa, obtidos por meio de 1,2-dicloroetano, observaram a formacão de composto de interacão do petxe com o solvente. $\mathbb{E}_{3}$ se composto, o cloreto de 2 cloroetil-trimetilamônto, não é to talmente extrafdo pelo metanol, no processo de tratamento $e_{\text {, }} 0$ concentrado, fornecido a ratos na proporção de $50 \%$ na ração, mostrou-se altamente tóxico.

YANEZ e col. (103) relataram a qualidade dos concentrados protéicos obtidos en Quintero, por utilizaça de hexano e ou etanol. A análise de várias partidas mostrou, na utilização protétca lf́qtida, valores de 63,5 a 73,9, sendo de 71,3 para a caseína. Os mesmos autores constataram, também, que ratos alimentados durante catorze semanas, com rações contendo $24 \%$ de um dos produtos obti os por meio de etanol, mostraram crescimento semelhante ao de anima is alimentados com casefra. (*) "Indice de lactância", seguizdo os autores, corresponde $\dot{a} v a$ riagão de pêso do conjunto mấ-ninhada (até os 14 dtas de tdade) por grama de protelna ingerida nêsse perfodo. 
Teste oom ragôes oontendo $30 \%$ de outro produto, obtido por extragão con hosano e etanol, oferectdas a ratos por três gera sôes, revelaram ser a protelna de boa qualidade, sem evidenotar toxtcidade. A adigão de listna não elevou o valor btológico da protelna que, entretanto, era aumentado pela adicão do me. tontra.

o valor btológtco da protelna a compostgäo de conoentrados obtidos na Afrtoa do sul, por mato de etanol e a partir de pelxes como jurel, sardinias e merlussa, foran apresentados por DREOSTI (15) (16). A oul utt1lsagëo protétoa Ifqutda fot comparivel à da casetra a à de concentrados da "Tiobin".

Na Indta, INELRT e co1. (37) propararans, en laboratórto, concentrados de oardinha (Cluper lonateepa), tzando o etanol como solvente. O produto obtido fot a rmaze. nado em latas e conservou, durante dose meses, as suas propriedades organoléptioas, mostrando-se bastante aceltável para consumo. O seu coeftciente de aflocicta protétca revelou-se próxtmo ao do lelte desnatado |SFURPALKFAR o 001. (87)|. A análtse dos amtnocictdos essenctats de zon concentrado da mesma ortgem fot realtaada por KADKOL e IAHIRY (33).

$$
\text { Nas Plltptnas, NLaARE - BAIAN }
$$

(1) pre pararan, também en laboratórlo, concentrados do anohovas (stole phorus somereontl sêcas ao sol. A extraçäo fol felta por metó de stanol, e os concentrados resultantes mostraram-se inodoros

e tnsfpidos, apresentando conteuido de amtnocioldos e valor bloló gico comparávets aos da caselma.

Vários concentrados já foram, também, produztdos por meto de tsopropanol, dando orlgem a produtos de atto valor nutriotonal.

Un concentrado protétco de misculo de basa Ihau, obtido por extragâo com tsopropanol, fot testado por MORRISON e CAMPBEIL (61), que verificaram ser o seu coefictente de eficaicla protétca superior ao da casetra, se comparados ao nivel de 7 ou 108 de protelna na rasãos todavia, ao nível de 15\%, as duas protelnas mostraram o mesmo coefictente. Os autores não notaram diferenga otgnifloativa no pêso do flgado, de rins o de supra-renats, de antmats altmentados com ambas as pro telnas, nom tampouoo no teor de Ifptdes hepáticos. 
IAARSEN e HAITKIIS (40) estuda ram un produto análogo, que se mostrou supertor à casefna e à albunina do ôvo. Verificaran que farinhas de vísceras e de flgado de petxes pos sutam batxo valor biológico.

POIER (78) consegutu conoentrados de arenques (petxe gorduroso) e de bacalhau, obtidos com isopropanol. o outor uitilizou arenques intetros e vírtas porgóes de bacalhau (misoulo, bacalhau descabecado, descabegado e esviscerado o res tos da filetagem). o coeficiente de eficácia protétca que obser vou fot elevado, em comparacão ao da caseína $(2,50)$ o 0 fato fot $n f t i d o$ nos concentracios de bacalhau integral $(2,64)$, de misoulo $(2,97)$ e de arenque $(2,74)$. Fot particularmente elevado o teor de I isina nos concentrados, que mostraram boas qualidades organolépticaso

Recentemente, o "Bureau of Comnerctal Pish eries" aiturilgou uri. processo desenvolvtio em seus laboratórios ut II zável comerctalmente (99), baseacio na extragão com tsopropanol a partir de peixe dos gêneros Urophycis. Leriuccius e Theragra. A procusão experimental en laboratório, com o Urophy cis chuss, mostrou a posstbilidade da obtença de un produto inodoro, insípido, estável mesmo após 9 meses de armazenamento $e$ com alto teor de Iisina utilizável. o teor de metionina tamo bén foi elevado e o coeficiente de eficicia protélca superior ao da casefna. Testado exaustílamente, o produto não se inostruu tóxico para ratos.

Parece-nos interessante verificar o valor mutrictonal de conccntrados obtidos com outras espéctes, espectalnente de petxes gordurosos, que são os que representam, 86 guido LOVERS (47), os matores potenciats pesquetros, em grande parte desviados para a alimentacão antmal na forma de farinhas. Poucos estudos existem sôbre concentrados protéicos de peixes de água doce. Dentre os autares que se intes ressaram pelo assunto, podemos citart DE (3), IAACH e col. (52) que estudiaran concentrados não desengordurados. Por outro lado, $D E$ e HAINIALI (O) prepararam produtos desodortzados que, testados por $D E$ e col。 (10) en ratos jovens, mostraram salor máximo da ejicácia protétca ao nível de $10 \%$ de proteína na racão. Ehn 6 anostras ensatadas, os valores vartaram de 1,9 a 2,3 in e cal. 
(11)!

Noo vários concentrados desodorisados obtidos a partir de diferentes métddos e matérias-primas, verifi caram-se frequentemente grandes variasôes no valor biológico da proteína. BENDER e HAIZELBEN (4), analisando produtos de di versas origens, encontraram vartasão de 18 a 80 nos valores in dicativos da utilizaçấ protéica Ifqthtda. MORRISON \& MaLAUGHAN (62) e MORRISON e SABRY (64) também constataram variagões na eficáota protélca de divorsos concentrados obtidos por diferen tes métodoss os menores valores foram encontrados em amostras com strats de superaquectmento, as quats mostraram, também, uma diminutgäo do teor do Itsina e de metionina utilizáveis. A importânata do tipo de tratamento térmico já fot ressaltada por DONOSO e CO1. (13), IEA e CO1. (13), SAMBUCETTI E SANAHUJA (81) e por TAMEZ E DONOSO (102).

MORRISON (60), passando em revisto trabaIhos de vártos autoris, ressaltou a importânola que poden ter o método empregado e o solvente usado, na qualtiade do produto final.

MORRISON e col. (65) estudaram comparativamente, produtos obtidos com 1,2adiolorobtano e com isopropanol a partir das mesmas matérlas-primas: peixe total, misoulo a rs sfirwos da flletagem dêsses pelxes. Bncontraram variaçôes do co efictente de eficácia protéloa, que tendia a ser mator no conoentrado obtido com misoulos, e intermediário nos obtidos com peixe total; a diferenga, porém, só era significativa ao nível de $10 \%$ de protelins na ração e não no de $20 \%$. Os concentrados obtidos com isopropanol eram superiores aos obtidos com dicloroctano, ao ntvel de $10 \%$ de protelna, desaparecendo a diferenga quando êsae nível era de 20\%. As taxas de lisina e metiontna totais, bem como a de metionina digerfvel, eram mats altas nos produtos obtidos por meto de isopropano1. O estudo evidenotous a importâncic das partes consideradas dos petxes, do nível de protelina no ensato e do solvente usado, en relação ao valor blológico do concentrado. KUTRTZMAN e SNYDER (36) também encontraran diferengas no valor blológico da proteína, conso re sultado do método empregado $e$ da parie aproveltada do petxe.

DONOSO e TAKEZ (12) constataram menor uti İzaşão protéica a partir de produtos desengordurados por eta- 
no1, em comparaçäo aos mesmos produtos, porém não desengo raura dos.

A influêncta do 1,2-dtcloroetano fot partloulamente estudada. Asstm, LORISOIJ (59) veriftcous num con centrado preparado com ête solvente, a destrulf̧ão de parte da ntstidina a existênota de ntotidina e metionina não utiltzávets por ratos e que não eram liberadas por hidrólise enzlmáti ca "in vitro". Este efetto era menor noutro concentrado preparado cor toopropanol. NORRISON - NOAwO (63) compararam produtos obtidos com hexano, etanol, lsopropanol e dicloroetano, ve riflcaindo que êste últtmo oausava mals extensa destrulfão da clstina e da histtilina, diminuindo, além dtsso, a copactdade de 1 iberação dêsses dots aminoćcidos, $e$ também a da metionina, por nidrólise enzinática. Sugeriram que tal fato poderia ser devido à interacão do solvente com os grupos sulficirila da pro telna.

HOWE a Col. (29), estudando o valor bbolágtco da protelna de concentrados produztdos a partir de bacu1hau, no Canadá, e dos produzidos em Qutntiero, verificaram que a adifão de metionina, de lisina ou de ambos, não provocava au mento dos coeficientes de eftccicta protélca, que eram supertores ao da casetna.

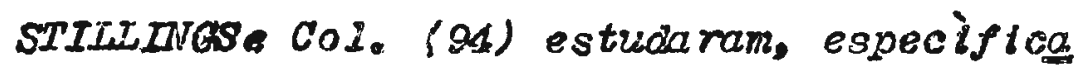
mente, a conoentrado produzldo pelo "Bureau of Commercial Fl sh ertes", vertfioando que o seu coefictente de eflcáota protélicu podic ser elevado pela adiçá de vártos aminocíctios, sendio a metiontina o principal.

En 1967, O FoD,A, (Food and Drug Administration) aprovou do is processos para a obtenção de concentrados protétcos (98) : un, baseado na extração com 1,2-dtcloroetano, e outro, con lsopropanol. Este último, como já dissemos, fol desenvolvido pelo "Bureau of Comercial Fisheries" e testado com o Urophycts chuss, com bons resultados, desconhecemos, porém, seu uso em outras espéotes de pelxes.

2.2 - Linerats nos concentrados protétcos

Nos concentrados de pelxe, além da rique. 
za em protelna, existe elevado teor de minerais. Poucos estudos, entretanto, têm sido levados a cabo sôbre seu aproveitamento btológtco.

Em trabalino realizado por SURE (97), dots concentrados protétcos, estudados como ínica fonte de minerals e protelnas de uma dada ração, mostraram-se tão eficazes na pro moção do crescimento de ratos quanto uma raçäo tsoprotétca losseina) e tsomineral (mistura salina de boa qualtdade)。 DU BRUTN e DREYER (17) verificaram que farthinas de petxe sul-africanas, adntinistradas a ratos jovens como ínica fonte de minerals, revelaram-se deficientes em potćssto. JAFifs (32) näo encontrou de fictências al imentares em ratos alimentados com raçäo contendo $80 \%$ de milino e 203 do concentrado protétco "Viobin", sem qualquer suplementasão vitaminica ou mineral, não foram avaliados porém, os minerais fornecidos pelo milino.

$$
\text { Já fol vertśtcado que o cálcio dos } 08508
$$

de pequenos petxes é bem aprovettado pelo organismo |BASU \& BA. SAK (3), IEVERTON E PA YATAL (45)|Estudos realizados com concentrados protélcos mostram fato idêntico: PRETORIUS $e$ VEHEWEYER (80) obtiveram boa retenção de cálcto e fósforo em convalescentes de hopahiorkor alimentados com dietas suplementadas por con centrado de petxe. SHURPALETLAR e col. (86) encontraram, também, boa retenção dêsses minerals em crlanģcs al imentadas com dieta básica de arroz, suplementada com alimento vegetal contendo con centrado protétco de sardinina. SPENCER e col. (91), alimentando pessoas com dietas suplementadas por concentrado de peixe, ver 1 ficcram fato análogo. SHAPIRO e col. (85) relataram, recentemen te, que a adição de pequenas peroentagens de concentrado de pef xe a dietas raquttogentcas melhorava os estados de raquitismo $e$ osteoporose.

Os minerals dos concentrados de petxe, na optnião de vários autores, têm importâncto na prevencão da cárie dentál. . BUTNER e MUHLER (6), OPUZYNSKEA (74) e STEPHAN (92) (93), encontraram diminuţ̧ão da ocorrêncta de cárte em ani mats alimentados com racōes enriquecidas com os referidos concentrados. Este último verificou também que essa diminutgão, evtdente já com pequenas quantidades de concentrado, era propor clonal à percentagem de suplemento adicionado à raçäo. Outros autores chegaram ao mesmo resultado, empregando quantidades ele 
vadas de suplemento I NIZEL e c01. (71) CHAYET e co1。 (7) I. Como se sabe, o teor de fliior nos pelxes e pescados é elevado I HARVBT (28), MaLURE (18) (49), SCRMTTZ E DA SILVA (84), IJALDBOIT (101) 1. estando dtstrtbul do, princtpalmente, nos ossos e escamas I BROWN e col. (5) I, fato que expltoa a riquesa em flíor dos concentrados obtidos

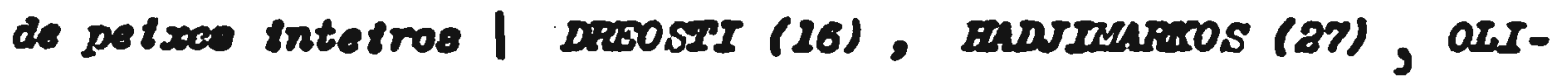
VEIRA (73), ZIPICI e col. (105) I.

o efetto benéfico observado na prevenção da incidêncla de cárte pode, eventualmente, ser atribuldo ao halogênto, wha vez que já fot vertficado que, entre certas po pulaçôes que faztam largo uso de petxe na dteta, havta inct dêncta stgniftcativa de esmalte manchado, ao lado da baisea in cldência de cárie, apesar de a ágra não conter elevados teores de flior I SOGVAES (83), SOGIAES e ARMSTRONG ( 89) 1.

A posstbiltdado de poder a ingestão prolongada de concentrados protétcos de peixes acarretar o apare cimento de esmalte manchado fol lembrada por HADIMARKOS (26) (27), que inststitu na necessidade de se fazeren estudos para conhecer com precisão o aproveltamento biológtco do halogênto.

Essas observações devem chamar a atenção do bromatologlsta, porquanto podem, eventualmente, ter stgnif 1 cado de alcance santtárto.

Com efetto, não mats se discute o fato de que concentragôes de 1 ppm de fluior na água de beber são eftcases na prevengão da cárie e tue guantidades ligeiramente supertores podem provocar flluorose dental

$$
\text { Aspectos já estudados do metabolismo do }
$$

halogênto mostram que $\hat{e} l e$ tende a flxar-se nos ossos de antmats jovens en mator quantidade do que nos de antmals velhos |ZIPIIN e LKLURE (104)|, fato também veriftcado para o homem |JAGRSOSS $\mathrm{E}$ WEIDMANW (30)|.

Por outro lado, dletas raquitogêntcas pro rocam aumento da concentraşao de flíor nos ossos |ZIPKIN e col. (106)/, estados de desnutrição, espectalmente a escassa ingestâo de cálcto, Já foram assoctadas a sintomas de fluorose | MASSLER e SHOUR (54), MURBAY e WILSON (69) |。

Todavia, o aproveitamento blológtco do 
do flúor natural dos alimentos é, geralmente batso, havendo proba bilidade de que o flíor dos concentrados de peixe não seja total mente uti Itado.

De fato, o alto conterido de cálcto e fósforo dêsses produtos pode diminutr a absorgão e,portanto, a fixação do flúor. $A$ influência dos fons referidos na flxacão do flúor já fä apontada por vártos autoressl DONOTAN \& MUHLER (14), IAWREWZ e MTTCHELT (41) (42), POURCHET-CAMPOS (76) (77), STOOKEY e colo (95) (96), WA GUER e MUHIER (100)l. Recentemente, num simpós to sôbre o firior, fot ressaltada a importância do conterído de cátions como $\mathrm{Ca}^{+2} \mathrm{Ng}^{+2}$ na prevengăo de fluorose, em regioês cuja água tinha alta concentragâo de flúor |MARIER (53)|

Ja" fol demonstrado que o flúor na forma de

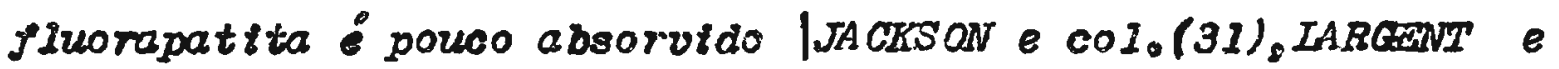
HETROTH (39), MCLURE e col. (50) ssabe-se, também, que o flúor pre sente nos $08 s 08$ de petxe encontra-se sob essa forma de fluorapatito |BROWN col。(5)laNestas condifoês, é ifcito supor que o flú or dos concentrados de petxes também seja pouco aprovettado:

Confirmando tal suposiçäo, podemos referir os trabalhos de BUHLAR e STOQKET (66), que constataram o batxo aproveftamento do firior contido em conohas de ostras:LEE e NILSON (44) estudaram a fiseaço do flúor naturas presente no salmäo e na cavala, verificancio que era batsa e que correspondia a cêrea de $1 / 3$ da obtida com outras racöes contendo NaF ou CaForacentemente, PLIERS (75) obteve aprovettamento de $6 \%$ do flúor ingerido, quan do ête era proventente de lambaris.

Até agora, parece que os ínicos trabalhos rea. Itzados para determinar a utilizacäo biológiaa do flúor de concentrados de peixe foram os de SPINCER e col.(90) e os de ZIPKIN - colo(105) Estes ültimos prepararan racóso con concentrado do p peixe Urophusts ehusg obtido por neio de isopropanol a contendo 20,50 \& 80 ppin de flúorsvertficenain que o aprovettamento era, res pectivamente, de 23,28 \& 1300 aprovettamento de flúor dessa fonte fol infertor ao conseguido com ragōes contendo NaP, na mesma concentragäo.Todavia, SPENCER (90) encontrou aprovettamento egutwlenta para as arks fontes. 
Recentemente, $O F_{0} D_{0} A_{0}$ (98) limitou em 100 ppm o conteúdo máximo de flúor em concentrados protétcos de pelxes, adnititndo una ingestão díría de até $20 \mathrm{~g}$ do produto, como suplenento altnentar. Essa Itmitaçäo decorreu da posstbilidade aventada de poderem os teores elevados de flúor, existentes nos concentrados obtidos de pelxe integral, vir a prowcar sintomas de fiuorose. 


\section{3 - MOITAGER DA EXPERIÊHCIA}

A nossa expertência visou determinar o aprovettamento blológtco da protefina e de alguns minerats presentes em concentrados protétcos destdratados, desengordurados $e$ desodortzados, de ttlápta e de sardinha.

Como protelna padrão, para efolto de comparação, uttlizamos a caselna.

Os antmats empregados foram 54 ratos albt nos, alojados em gatolas indtviduats e divtdidos em nove grupos de sets ratos.

Obtlveram-se asota os grupos $T, S, T_{1}$. $s_{1}, C_{1}, T_{2}, s_{2}, C_{2} \in \sigma^{0}$, que recoberam o segutnte tratamento:

Grupos (I): $T_{1}, S_{1}, C_{1}$, subrietidos a a raçôes contendo $10 \%$ de proteina:

Grupos (Z): $T_{2}, S_{2}, C_{2}$, submetidos a raqões contendo $20 \%$ de protelna.

Nestes 6 grupos, as fontes de protefna foram, respectivamente: concentracio de tllápla (grupos $\mathrm{r}$ ), de sardinha (grupos s) e caselna (grupas C), näo receberam qualquer outra fonte de protelina na ração, mas receberam suplementagâo com mistura salina segundo níveis ótimos para o cresctmento.

Grupos IE $E$ - receberam roçöes contiendo $10 \%$ da proteina dos dots concentrados respectivos, porén, sen qualquer suplenentagäo mineral. Westes grupos, portanto, os 
concentrados representaram a ínica fonte de proteína $e$ de minerafs.

$$
\text { Gripe } \epsilon^{0}-f o i \text { sacrificado no prineiro }
$$

dia da experiêncta, para que pudéssemos obter a composiğ̃o aproximada da carcaga dos animais no inteio da mesima, servindo os dados com contrôle inicialo

o planejamento descrito permititu o estudo do valor biológico da protetna, bem como da utiliagcão dos minerais. 
$s_{0} 2-2 x$

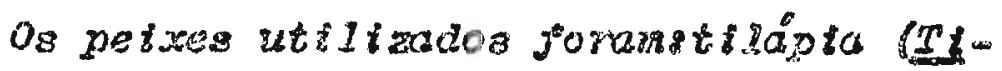

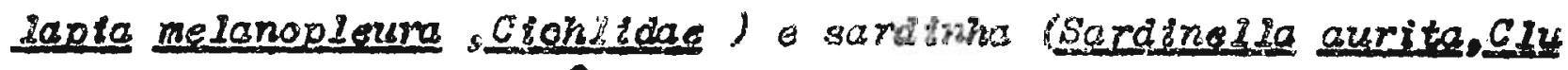

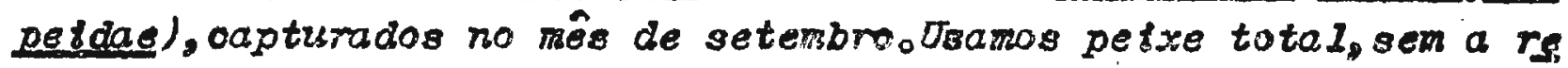
tirada de escamas, wósceras au cabegas。

a) Tliånic -joi obtida nos tanques de ori ortação da Estação Experimental de Plsctoultura de Piraçununga (*). Os pelxes capturados, de ambos os sexos, mediam de 9 a 16 on de comprlmento e foran transportados para o laboratório en calixas de isopor, contendo gêllo foram lavados em água, triturados no mesmo dis om moedor de carme, misturados oom tsopropanol a processados no dia seguinte.

b) Sardinha -joi. obtida no comérejo 20 .. cal, medindo de 13 a $18 \mathrm{~cm}$ de comprimento. Sofreu o mesmo tratamento que o do material anteriormente refertio.

$$
\text { 4.2-Animal de experimentação }
$$

0 antma. ut ilizado foi o Rattus noruegious, varodibtnus Rocientif , maoho, de idade entre 23 e 25 dias, da raga "Wistar", obtldo a partir de colóntas mantidas en nosso laboratórto.

$$
\text { -.-0-0-a- }
$$

(H) A gradecemos ao Dro Fuad Algazur ad Estaça Experimental de Pisetcultura de Piragunang, a abenc šosa cooperação represenw tada pelo fomecinento dos peixes. 
$4.3-G a i 01 a$

A gatola utilizada fot do tipo metabóltco, idealizada em nosso laboratório |zUCAS e col. (108)l. Ela permite, con un bom grau de precisão, o contrôle da ração ingertda formecendo elevado ínibe de recuperacano.

$$
\begin{aligned}
& \text { 1.4 - Bações }
\end{aligned}
$$

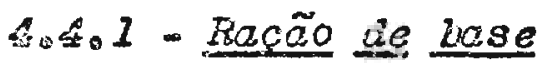

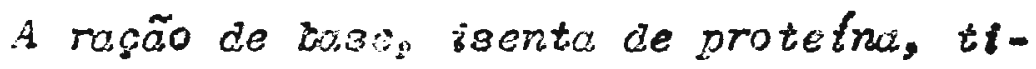
nha a seguinte composţçäo:

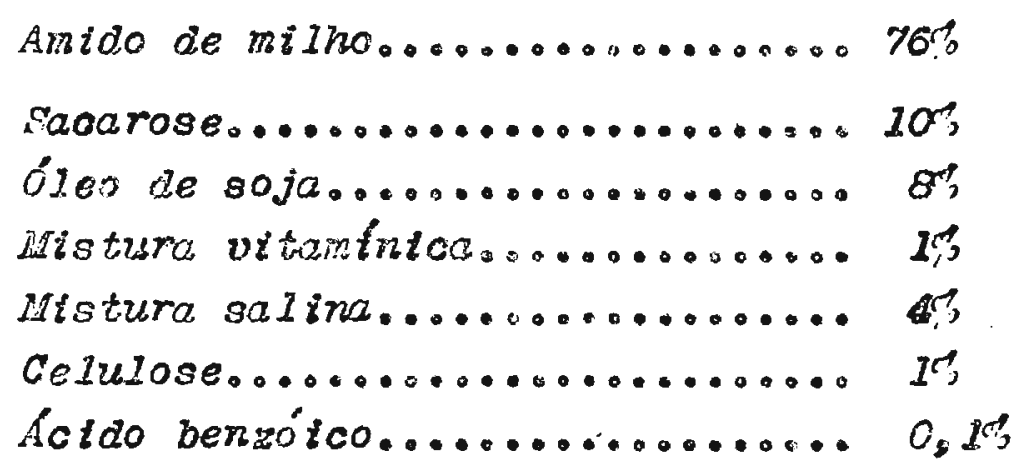

A mistura sazina utilizada apreserika a seguinte composigço

Carionato de Cálcio............16,600\% Fosfa to Tricálcico........0.....47, 300\%

Sulfato de Cobre.0000.0.0.000 0,027\% Citrato fiérrico.0oso.........00 0,333 \% Sulfato de ragrésto........... 5,000\% Sulfato de klanganes............ 0,417\% Cloreto de Fatássto.0.0.0.0.11,600 \%

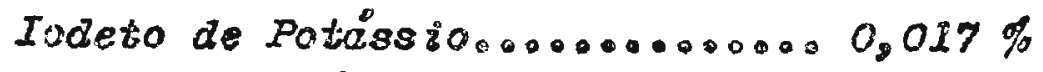
Cloreto de Sódio.0000000000000 6,600\%

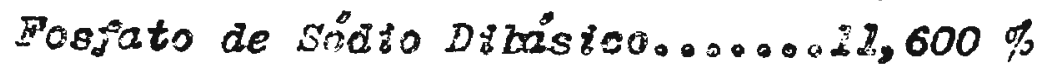
Carbonato de Zinco ono0000000000 0,217 of 
A mistura vitamtnica, por nós preparada, apresentava a seguinte composição:

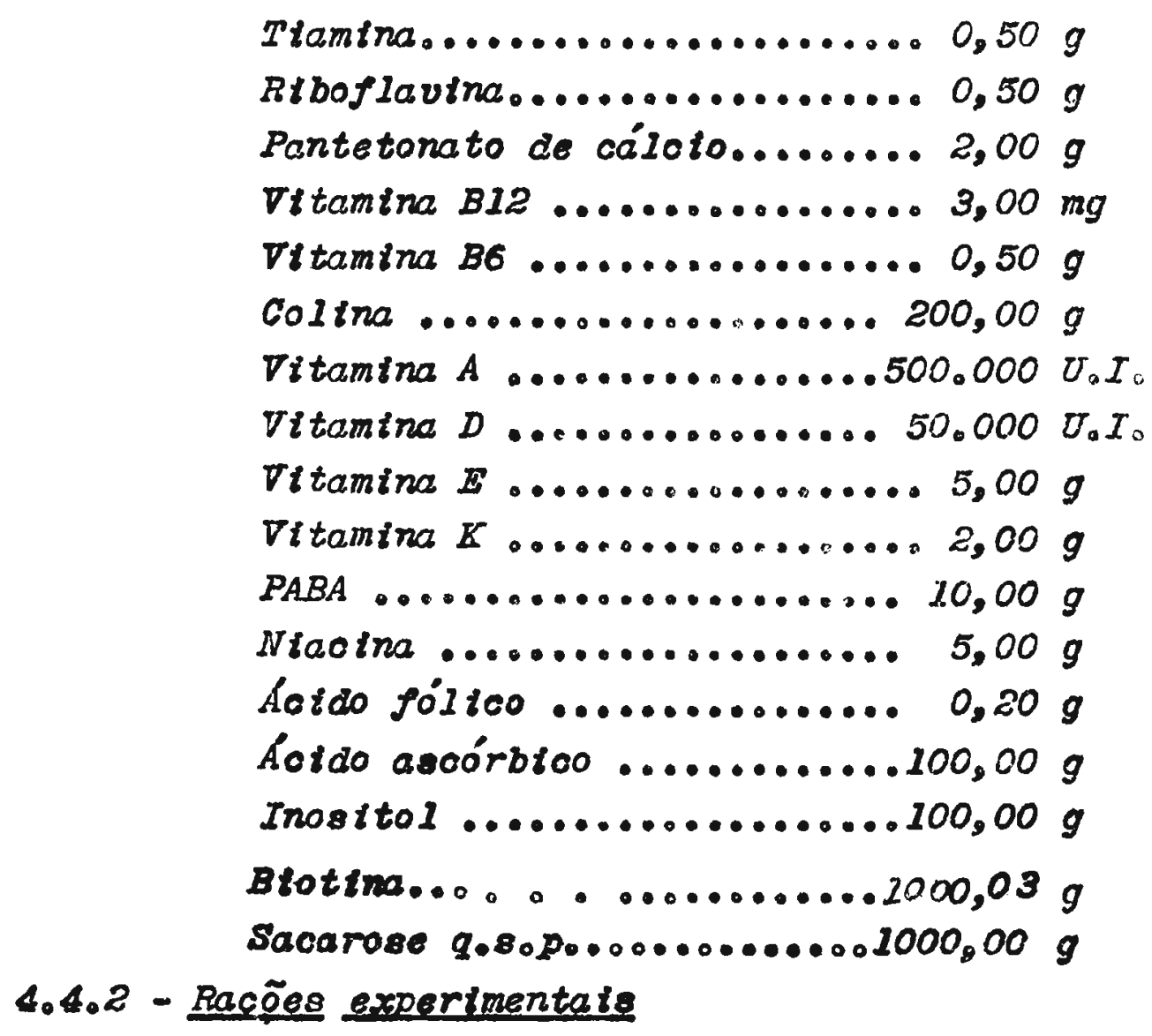

A partir da ração de base preparamos as rações expertmentals, adictonando as fontes protéicas às expen sas do amido e da mistura saltna, de forma a obter o nivel desejado de protelna ( 10 ou 20\%), e de minewis (4\%).

Procuranos, desta forma, obter rações iso nitrogenadas, isominerals, isooálolcas, isofosfatadas e isocalórtcas, que form fornectdas aos antma ts dos grupos (1) \& (T, $\left.S_{1}, C_{1}\right)$ e dos grupos $(2):\left(T_{2}, S_{2}, C_{2}\right)$. As rasốes recebe ram a mesma designação do grupo respectivo.

Nas rafões $T$ e $S$, fornectias aos antma is dos grupos $T$ e $S$, a mistura salina da ração de base fol elimi nadage fim de que os concentrados pudessem constitutr ínica fonte de protelna, bem como de minerais.

- tratamento desorito encontra-se esquema tizado no quadro $I$.

Como protelna padrão, usamos uma caseina alimentar contendo $80,0 \%$ de protelna, 5, we minerats, $11,2 \%$ 
de ranidade e $3,5 \%$ de Ifpides e glf́ctdes.

$Q U A D R O I$

\begin{tabular}{|c|c|c|c|c|c|}
\hline $\begin{array}{l}\text { Concentrado } \\
\text { (Ponte protéfca) }\end{array}$ & arupo & $\begin{array}{l}\text { Concen } \\
\text { trado } \\
\text { adto. } \% \\
\%\end{array}$ & $\begin{array}{c}\text { Protelna } \\
\text { na racâ } \\
\%\end{array}$ & $\begin{array}{l}\text { Misture } \\
\text { salina } \\
\text { adio. } \\
1\end{array}$ & $\begin{array}{c}\text { Mtnerats } \\
\text { na racáo } \\
\$\end{array}$ \\
\hline \multirow[t]{3}{*}{ TILÁPIA } & $T$ & 12,4 & 10 & $-\infty$ & 1,5 \\
\hline & $T_{1}$ & 12,4 & 10 & 2,5 & 4,0 \\
\hline & $T_{2}$ & 24,8 & 20 & 1,0 & 4,0 \\
\hline \multirow{3}{*}{$S A R D I N B A$} & $s$ & 11,6 & 10 & $\ldots$ & 2,2 \\
\hline & $s_{1}$ & 11,6 & 10 & 2,8 & 4,0 \\
\hline & $s_{2}$ & 23,2 & 20 & 1,6 & 4,0 \\
\hline \multirow[t]{2}{*}{$C A S E$ tIVA } & $c_{1}$ & 22,4 & 10 & 3,4 & 4,0 \\
\hline & $c_{2}$ & 24,8 & 30 & 2,8 & 4,0 \\
\hline
\end{tabular}

A análise das racões asstm preparadas mostrou a compastção apresentada na tabela 1. 


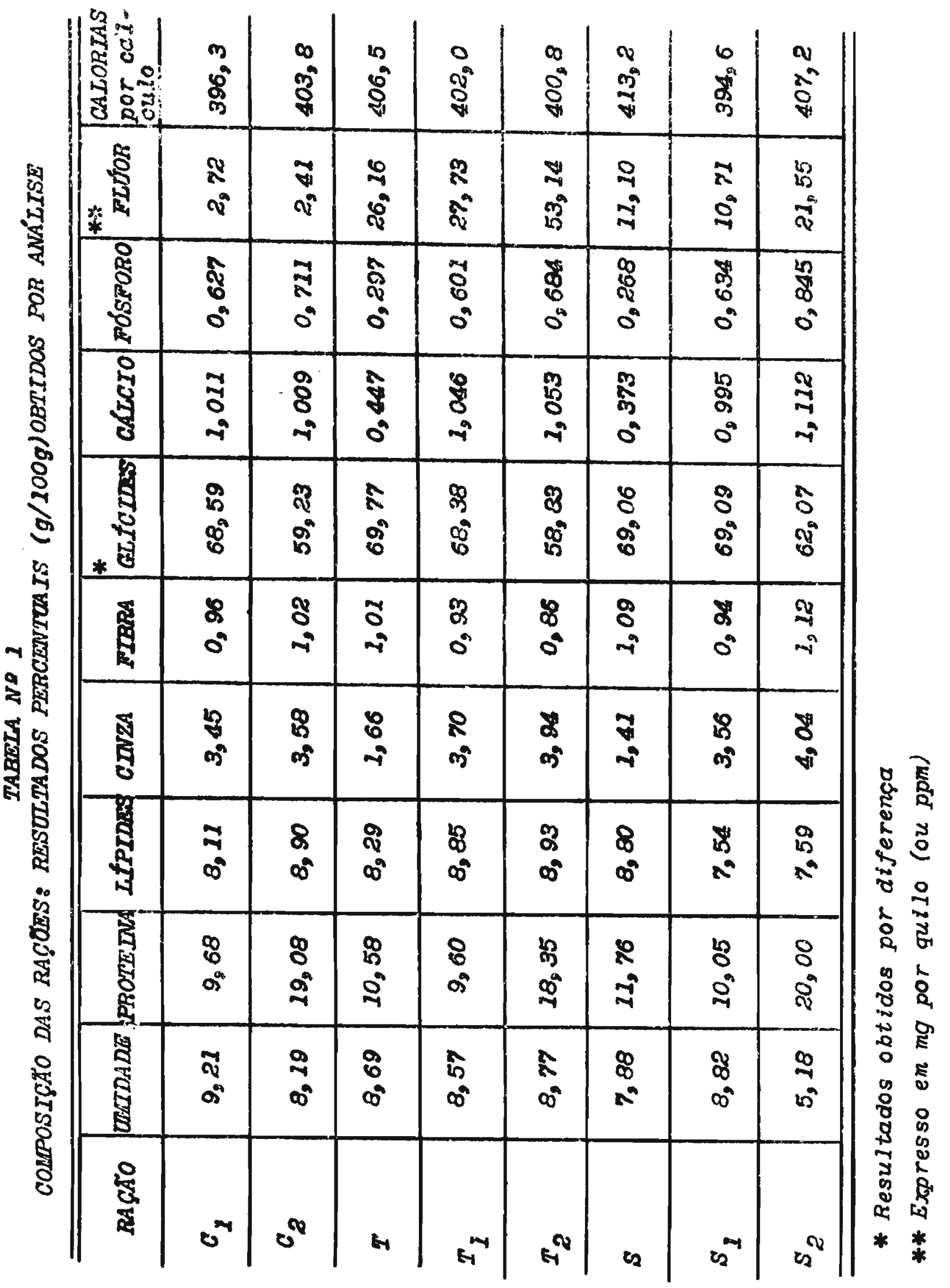




\section{5 - LETODOS}

5.1 - Preparo dos concentrados protéicos*

No preparo dos concentrados protétoos, procedemos à desidrataģão, desengorduramento e desodortzação do material ( petxe triturado), por extragões sucessivas com isopropanol, segundo o método precontzado pelo "Bureau of Commercial Fishertes" (99), segundo o esquema segulntes cêrca de 20 qutlos de pelxe foram tratados oom 30 litros de tsopropanol a $91 \%$, durante 12 horas, após o que a mtstura fol agttada por uma hora e centrifugada. A torta fot, então, extralida com 15 Ittros de isopropanol a 91\%, em aqueotmento a $70^{\circ} \mathrm{C}$, por uma hora, em reotplente com camisa de vapor e sob agitaçäo. A s8gutr, a micela fot centrifugada, mantendo-se a temperatura. Nas duas extragōes seguintes, utilizamos lsopropanol a $99 \%$ a mesma temperatura, sendo que na tercetra extrasão ut 11 tzamos doze Ittros e, na quarta, otto litros do álcool.

No preparo do concentrado de tilápia, os petxes foram divididos em três porgôes, sendo a extraçâo prat cada em contra-corrente. Os volumes de tsopropanol foram ajusta dos em cada extração, a flm de manter as proporções já refertdas.

$$
0-0, \cdots,-.
$$

(*) Agradecemos à Cadeira de Tecnologia Geral e Químico-Parmacêutica a permissão do uso de seus aparelnos. 
Após o processo de extraç̃o, as tortas obtidas foram aquectdas a $60^{\circ} \mathrm{C}$ durante 10 horas em corrente de ar e, finalmente, por mats 4 horas a $80^{\circ} \mathrm{C}$. A segutr, o material fot pulvertiado em moinho de bolas e tamtzado em penetra (malha de $0,177 \mathrm{~mm}$ ). O pó obt tdo constitulu-se no concentra do protétco que, após análtse, fol utilizado para o preparo das racões.

\section{2 - Preparo das rậ̃es}

Após a mistura dos várlos componentes, as rações foram transformadas em massa por meto de goma de amtdo. Fcbricamos, então, um granulado vermicular, que fot dessecado a $40^{\circ} \mathrm{C}$, em corrente de ar. Esta forma de apresentagão da ração garante menor desperdícto por parte do animal, diminutndo o êrro no contrôle da quantidade ingerida. Além disso, permite melhor conservação e assegura homogene idade no decorrer de tô. da a experiêncta 1 LAsOLO e col. (38) 1.

\section{3 - Avaliação do aprovettamento blalógtco}

$$
5.3 .1-\underline{R a c \tilde{o} e s}
$$

Na avaltação do aproveltamento das rações preparadas, utilizamos, como lnatce, o coefictente de eficácta altmentar ( C.E.A.)*, que representa o aumento de pesso do antmal por grama de rasão ingerida.

$$
5.3 .2-\underline{\text { Protelna }}
$$

Para sua aval tação ut litzamos:

a) coefictente de eficácta protétca

(*) Food Efftctent Ratio (F.E. $\left.R_{0}\right)$ 
$\left(C_{0} E_{0} P_{0}\right) *$, que representa 0 aumento de pêso do antmal por gra ma de protelna ingertida ( segundo norma preconisadas pela A.O.A.C. (2)).

b) aproveitamento percentual do nitrogê. nio, ou seja, a percentagem de nitrogênio retida na carcaga do animal (obtida por análise), om relagão ao nitrogênio total ingertio.

\section{$5.3,3-\underline{\text { Minerais }}$}

o aproveltamento dos minerais fol obtido pelo cálculo da percentagem retida na carcaga do animal, em relação ao total ingerido.

Tanto no caso do nitrogênio, como no dos minerais, o total retido pelo antmal fot obtido da seguinte formas quantidade total na caroaga (obtida por análtse) após as 28 dias da experiêncta) menos a quantidade intctal (calculada pela análtse da caroaga do grupo $G^{0}$, e extrapolada segundo as diferengas de pêso dos animats).

$$
5.4 \text { - Análise da carcaga }
$$

\section{4 .1 - Preparo do material para análtse}

Após os 28 díss da experiêncta, os ant mals foram secrificados, sendo eliminados a estómago os intestinos. A carcaga fol pesada, subdividida, dessecada em estufa a $105^{\circ} \mathrm{C}$ e desengordurada. O material, sêco e desengordu rado, fot pulvertzado em liquidificador e guardado para análise.

$$
\text { o grupo } C^{\circ} \text {, secrificado no tempo cero }
$$
da experiêncta, após sofrer o mesmo tratamento, fot analtsado. Os dados médios, obtidos pela análtse da caraga, serviram como contrôle intetal.

$$
0-\cdots-
$$

(*) Protein Effictent Ratio $\left(P_{0} E_{0} R_{0}\right)$ 


\section{4 .2 - Determinasōe?}

até pêso constante.

\section{4 .2 .1 - Doldede}

Dessecagão em estufa regulada a $105^{\circ} \mathrm{C}$,

5.4 .2 .2 - Extrato etéreo

Ixtracão com éter etflico, em extrator

continue de soxhlet.

\section{4 .2 .3 - Resf(duo mineral Ltxo (cinga)}

Incineração a $550^{\circ} \mathrm{C}$ até pêso constante.

\section{4 .2 .4 - Nitrogênto}

Instituto Adolfo Luts (82).

Nétodo de KJeldahl, segundo técntoa do

\subsubsection{5 - Minerals (expeto Livor)}

a) Cálcto: método colorimétrico de FMRRO

e HAN (22).

b) Fósforos método de FISER e SUBAROW (23).

c) Perro: método que utilisa tioctanato, precontzado pelo Inst tuto Adolfo Lutz (82).

d) Sódto e potásstos fotometria de emissão de chama* As soluçôes padrão foram preparadas de forma a conter quantidades tdêntloas às dos slementos malores presentes nas soluçôes das anostras en análtse.

$$
\begin{aligned}
& 5.4 .2 .6 \text { - Determinacão do tivor } \\
& \text { o halogênto fot toolado do material sêco }
\end{aligned}
$$

e desengordurado, ut $t$ tzando-se o frasco precontzado por zuCAS - IAJOLO (107). Na quant tftcação, usamos o método colorimétrico de MEGREGLAN (55).

(*) Em fotômetro de ohama maroa Eletrosintese 
5.4.2.7 - Determinacão dos amtnoáctdos*

o triptófano fol determinado quantitativamente, após hidrólise alcalina, pelo método proposto por IIILEER (57). Os outros aminocicidos, após hidrólise em meio cloridrtco $6 \mathrm{~N}$, foram analisados em analisador de aminoácidos, Nodêlo Beckman $120 \mathrm{C}$, com coluna de troca tôntoa.

$$
5.5 \text { - Análise estatfstica }
$$

Na comparação das médias dos resultados obtidos em oada grupo, valemo-nos do teste " $t$ " de Student $e$ Fisher. A significâncta jol testada ao ntvel de $5 \%(P \quad 0,05)$. A fósmela utilizada fot a seguintes

$$
t=\frac{\bar{x}_{1}-\bar{x}_{2}}{\sqrt{\left.\frac{\sum_{i}\left(x_{11}-\bar{x}_{1}\right)^{2}+\sum_{1}\left(x_{21}-\bar{x}_{2}\right)^{2}}{N_{1}+\frac{N_{2}-2}{N_{2}} \pm \frac{1}{N_{2}}}\right)}}
$$

Nas tabelas são apresentados os erros-pa drão oaloulados segundo o proposto por MANTEL (51)

(*) Realtada pelo Departamento de Btoqufmioa do Centro Troptcal de Pesquisa e Tecnologia de Altmentos, Campinas, São Paulo. 
6 - DADOS ANALITICOS

6.1 - Compostgão dos concentrados protétcos

As tabelas 2,3 e mostram, respectivamente, a composigão centestmal, o teor em aminocictios essencl ats o teor de oálcto, fósforo, ferro, flíor, sódto e potág oto dos ooncentrados protétoos obttdos a partir do Tilápla e de sardinha. 
TABELA NO 2

COMPOSIGAO MEDIA CENIESINAL DOS CONCENTRADOS PROTLICOS.RESULTADOS EXXRESSOS EM $\mathrm{g} / \mathrm{l} 00 \mathrm{~g}$.

\begin{tabular}{|c|c|c|}
\hline \multirow{2}{*}{ IRAGAO } & \multicolumn{2}{|c|}{ CONCENITRADO } \\
\hline & IIIÁPIA & SARDINIA \\
\hline $\begin{array}{l}\text { unidade residual } \\
\text { protétna * } \\
\text { extrato etéreo } \\
\text { cinza } \\
\text { indeterminados } \\
\text { por atferonga }\end{array}$ & $\begin{array}{r}6,13 \\
80,75 \\
0,26 \\
12,20 \\
0,86\end{array}$ & $\begin{array}{r}3,10 \\
86,34 \\
0,10 \\
10,19\end{array}$ \\
\hline
\end{tabular}

*NX6.25

TABELA NP 3

TEOR DE ALGUNS LINERAIS NOS CONCENTRADOS PROTEICOS. RERSULTADOS EXXPRESSOS WM $\mathrm{mg} / \mathrm{lOOg}$ 。

\begin{tabular}{l|r|r}
\hline \multirow{2}{*}{ UINLYRAL } & \multicolumn{2}{|c}{ CONCENIRADO } \\
\cline { 2 - 3 } & TIIAPIA & \multicolumn{1}{|c}{ SARDINHA } \\
\hline Cáloto & $3.154,0$ & $2,866,0$ \\
Fósforo & $2.412,0$ & $1,918,0$ \\
Perro & 50,7 & 9,1 \\
Flíor & 22,9 & 8,2 \\
Sódio & 274,7 & 226,8 \\
Potáss to & 649,8 & 612,5 \\
\hline
\end{tabular}




\section{TABELA NQ 4}

COMPOSIGAOO EN AMENOACIDOS ISSSENCIAIS DOS CONCENTRA DOS PROTISICOS。RESULTADOS RXXPRESSOS EM g/lOOg DE FRO TELINA DO CONCENTRADO。

\begin{tabular}{l|c|c}
\hline \multirow{2}{*}{ AMINGÁCIDO } & \multicolumn{1}{|c}{ CONCENTRADO} \\
\cline { 2 - 3 } & TILAPIA & SARDINHA \\
\hline Isoleucina & 4,705 & 3,733 \\
Leucina & 7,296 & 6,050 \\
Lisina & 8,810 & 7,753 \\
Fenina Ianina & 3,973 & 3,448 \\
Tirosina & 3,305 & 3,013 \\
I/2 cistina & 1,045 & 1,974 \\
Metionina & 2,273 & 2,176 \\
Treonina & 4,528 & 3,581 \\
Triptofano & 1,560 & 1,569 \\
Valina & 4,390 & 4,708 \\
\hline
\end{tabular}

* Aminoćctio não considerado essenctal. 
6.2 - Curva de pêso dos antmais

o crescimento dos animais submetidos às racões experimentals, durante os 28 dias, está representado nos gráficosl, 2 e 3. A curva de pesso foi obtida a partir de 5 pontos, sendo o primeiro correspondente ao pêso inicial $e$ os seguintes às pesadas semanais.

As curvas foram agrupadas segundo a fon te protéica inclufia na dieta, a sabers(n? I) Caseina, (ns2) Tilápia, (no 3) sarotiniza。 
CURVAS DE PESSO

ORAPICO NOI

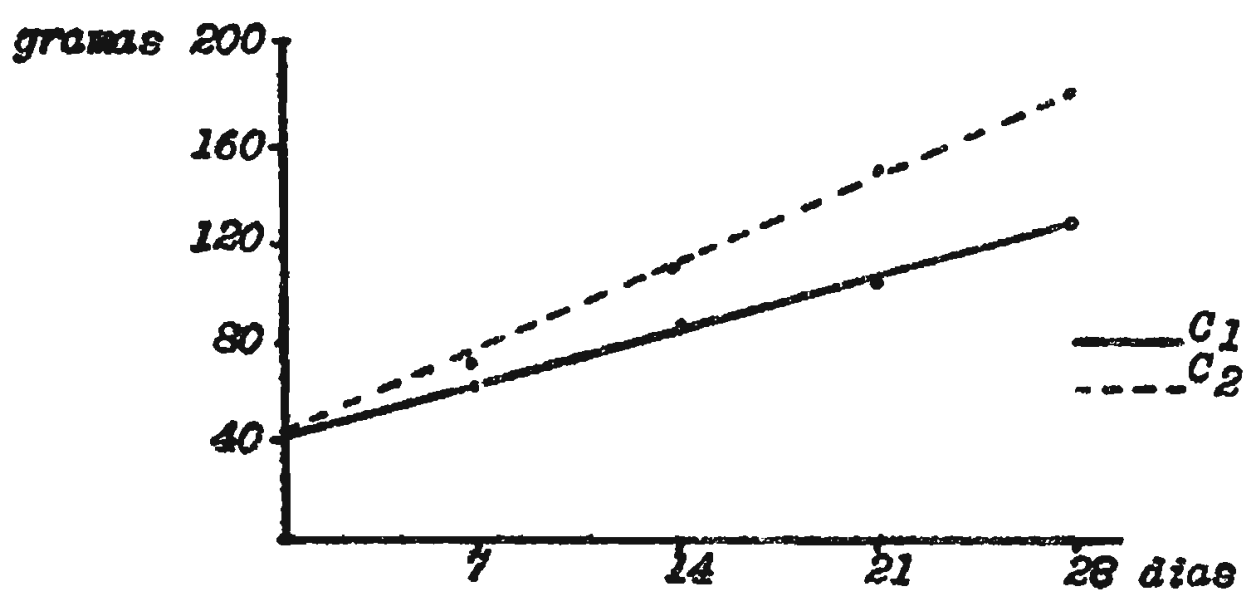

GRATICO NO2

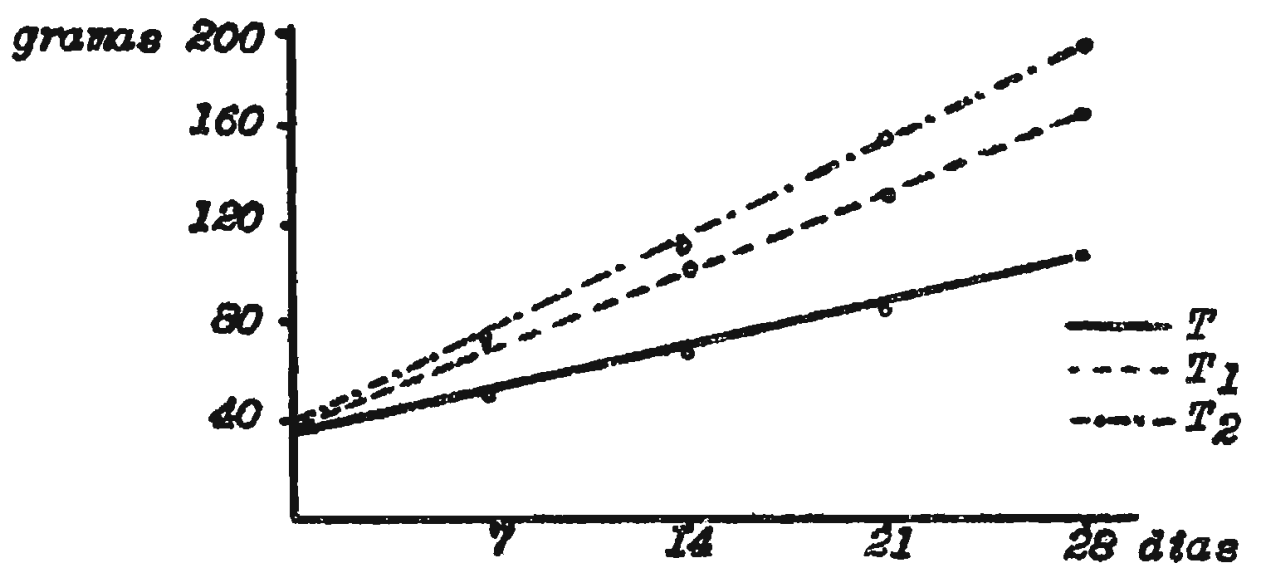

CRÁPICO NSB

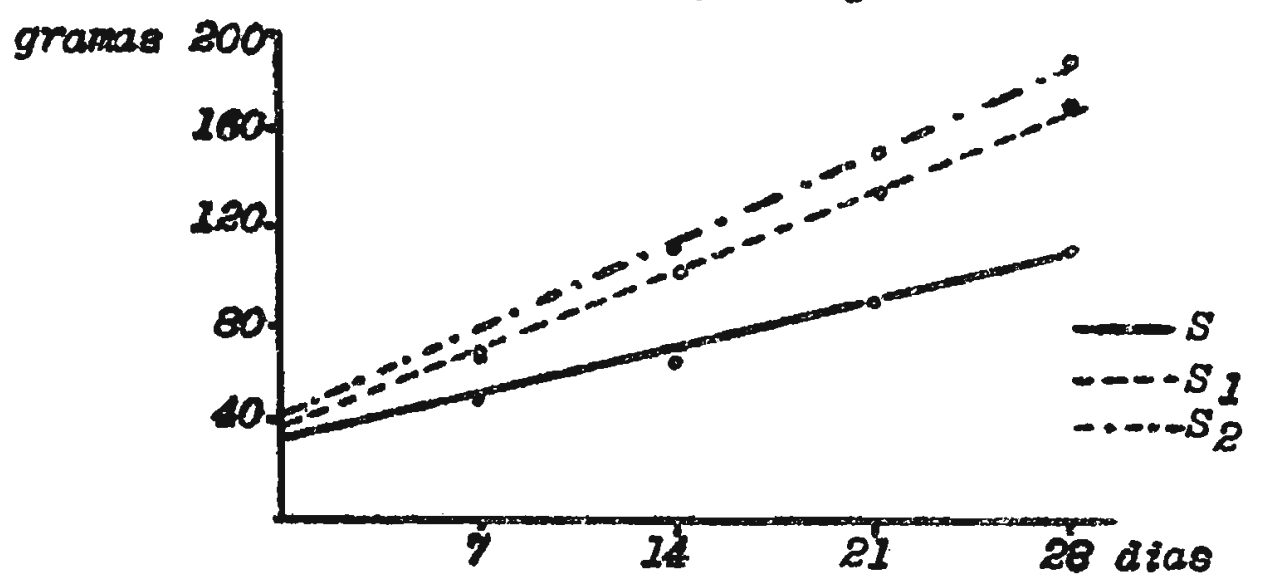




$$
6.3-\frac{\text { Cooftoiente de ofiocicta protétca e coofiotente de }}{\text { eficciola altmentar }}
$$

0s resultados reforentes ao coefloiente de oftccícta protétca, expressos através do ganho de pêso e calculados en trdices, constam da tabela 5, que mostra tambóm - pêso intetal e ftnal dos antmats, beth oomo a quantidade de rạcõo por êles tngerida durante a expertêncto. 


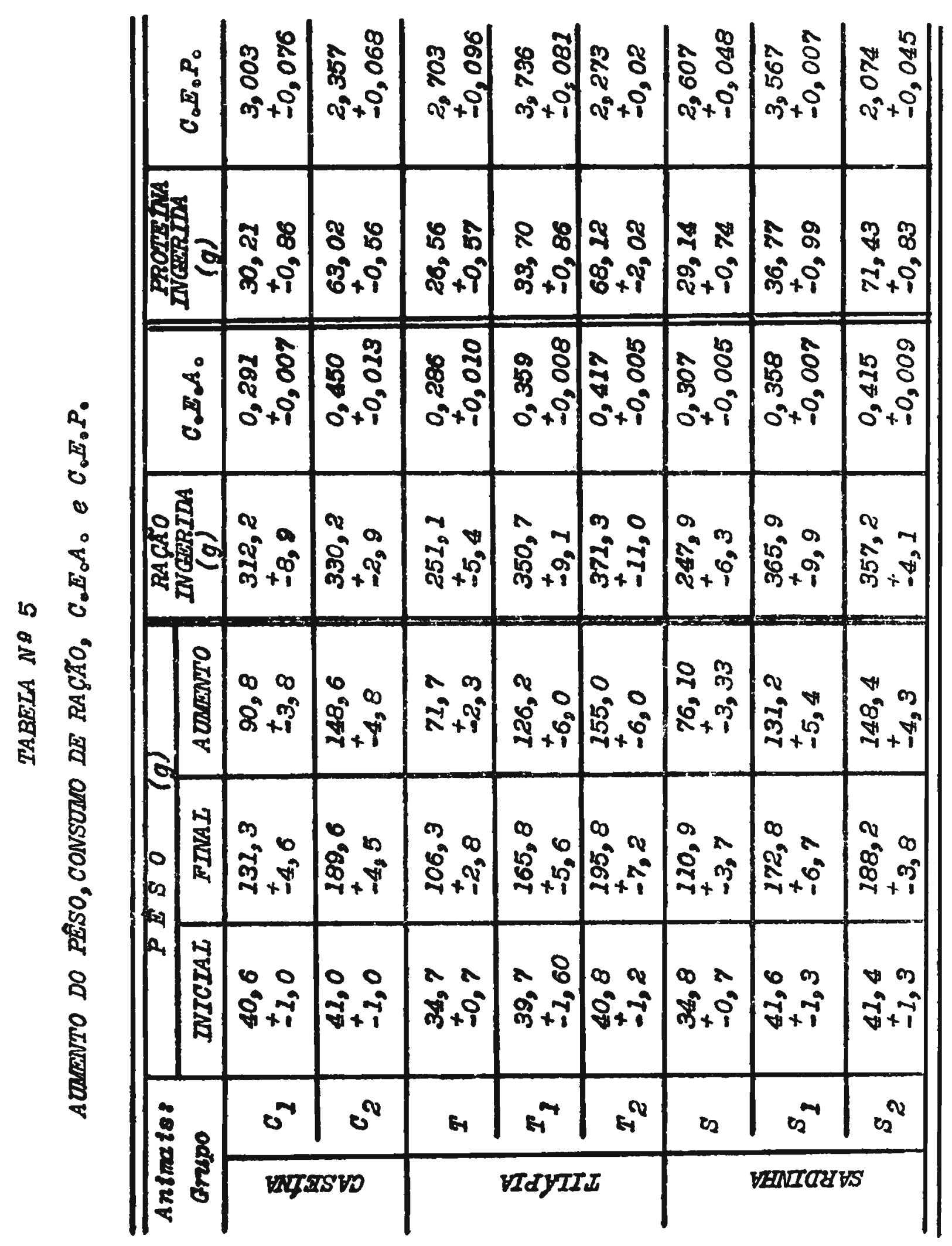


6.4 - Resultados obticos peía análise das carcagas

\section{4 .1 - Pêso e compostģão centestimal das caroacas}

a) Anima is de expertência - As oaroaģas dos animats de experiênota, analisadas quanto ao pêso e composí são oentesinal, após as 28 dlas, mostraram os resultados méalos que se enoontram na tabela 6. (página seguinte)

b) Animats do grupo cip - Na tabeics 7 enw contram-8s os resultados da análise da carcaga dos antmats do.

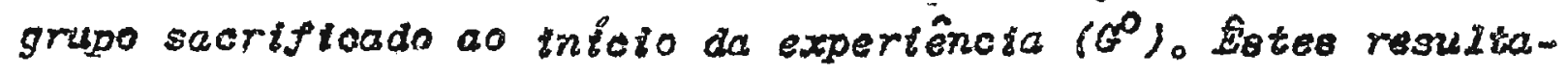
dos foram ut 1 tiados, por extrapolação, para caleular o nittrogê nio, oćloto eflúor intotats dos anima is em experienota. th tô. das as tobeias, quandio nos refertmos a resultado "intolal", refertmo-nos a êtes dados.

Na tabela 5 encontina-se, também, o pêsomédlo dos antmals e da earcago do mesmo grupo ( $F^{\circ}$ )。

TARELA NQ Y

\begin{tabular}{|c|c|c|c|c|c|c|}
\hline Antmats & \multicolumn{4}{|c|}{ PERCEIVIACM } & \multicolumn{2}{|c|}{ PESO (g) } \\
\hline Grupo & $N$ & $C a$ & $P$ & $F^{*}$ & Antmats & Caroaga \\
\hline$\theta^{\circ}$ & $\begin{array}{l}20,47 \\
\pm 0,06\end{array}$ & $\begin{array}{l}3,70 \\
\pm 0,10\end{array}$ & $\begin{array}{l}2,80 \\
\pm 0,09\end{array}$ & $\begin{array}{l}3,06 \\
\pm 0,31\end{array}$ & $\begin{array}{l}38,0 \\
\pm 0,43\end{array}$ & $\begin{array}{l}7,84 \\
=0,15\end{array}$ \\
\hline
\end{tabular}

(*) Expresso em ppm (partes por mithão)

(**) sêca o desengoriunada 


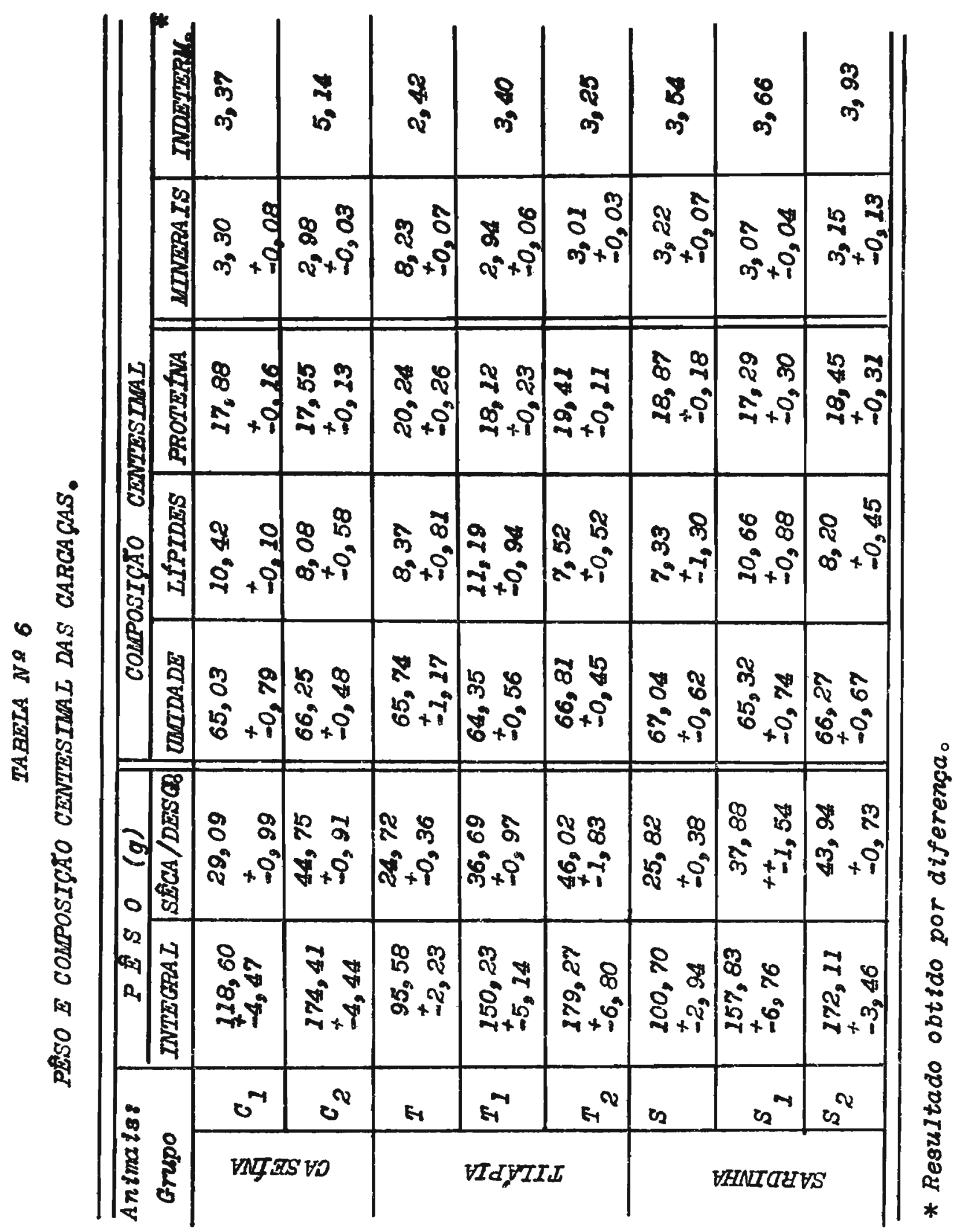


6.4.2 - Aproveitamento percentual do nitrogênio inge-

dados:

Na tabela $n: 8$ s encontramos os seguintes

a) Nitrogênto inicial lobtido segundo fol descrito en 6.4.1 b)

b) Nitrogênio total na carcaga após o témino da oxperiêncta.

c) Nitrogênio fixado.

d) Concentragão de nitrogênio na carcaga dos antmato.

e) Aprovettamento percentual a partir do nitrogênio ingerido. 


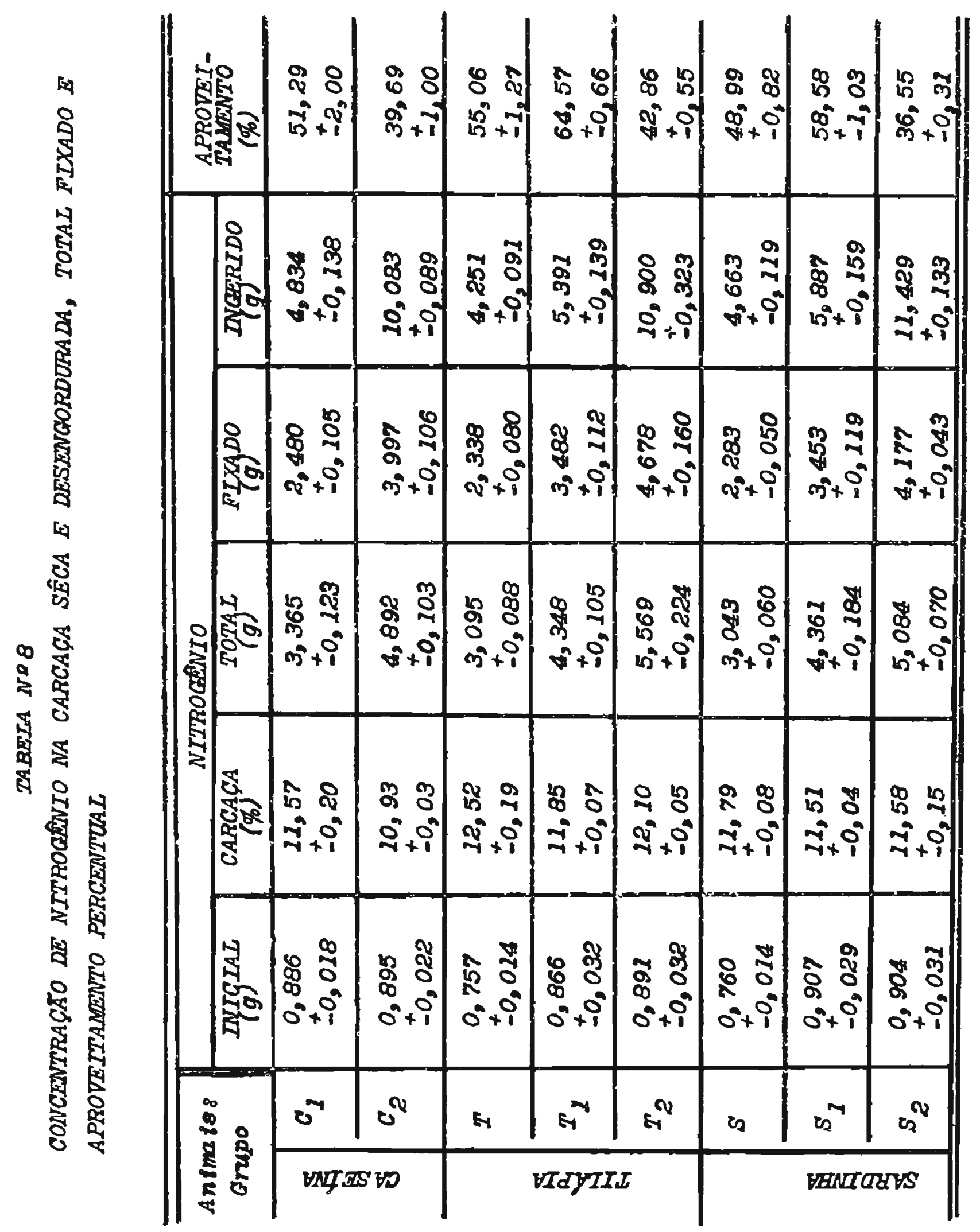




$$
\text { 6.4.3 - Aproveitamento percentual do cálcio, do fósfo }
$$

Nas tabelas 9,10 e 11 encontram-se os segutn tes dados, respectivamente relacionados ao cálcio, fósforo e flíor:

1 - quantidade intcial lobtida segundo fot deseri to en 6.4.1 b.

2 - quantidade total na carcaça apóa o término da expertência.

3 - quantidade fixada.

4 - concentrafão do mineral na carcaça.

5 - aproveitamento percentual a partir do ingerido. 


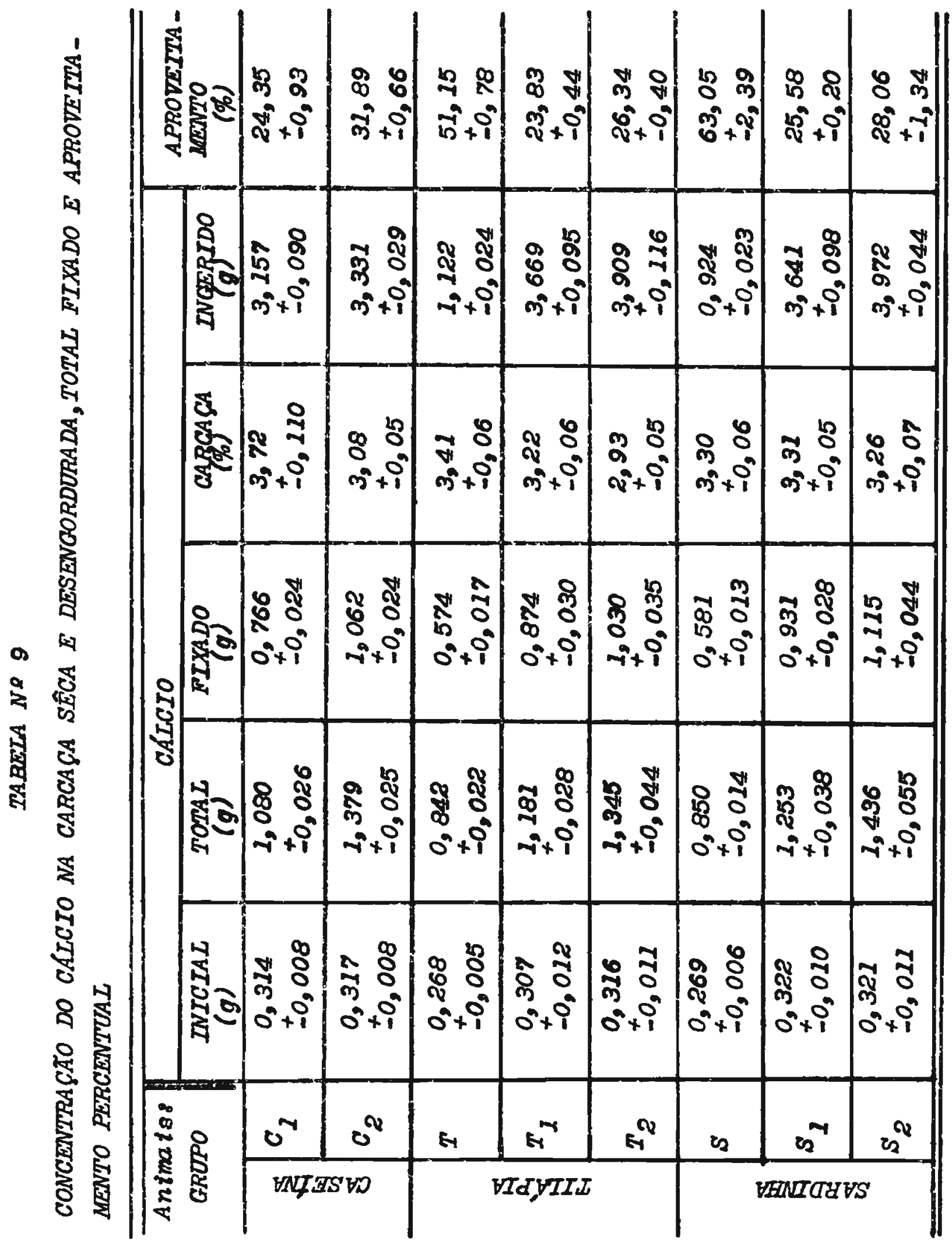




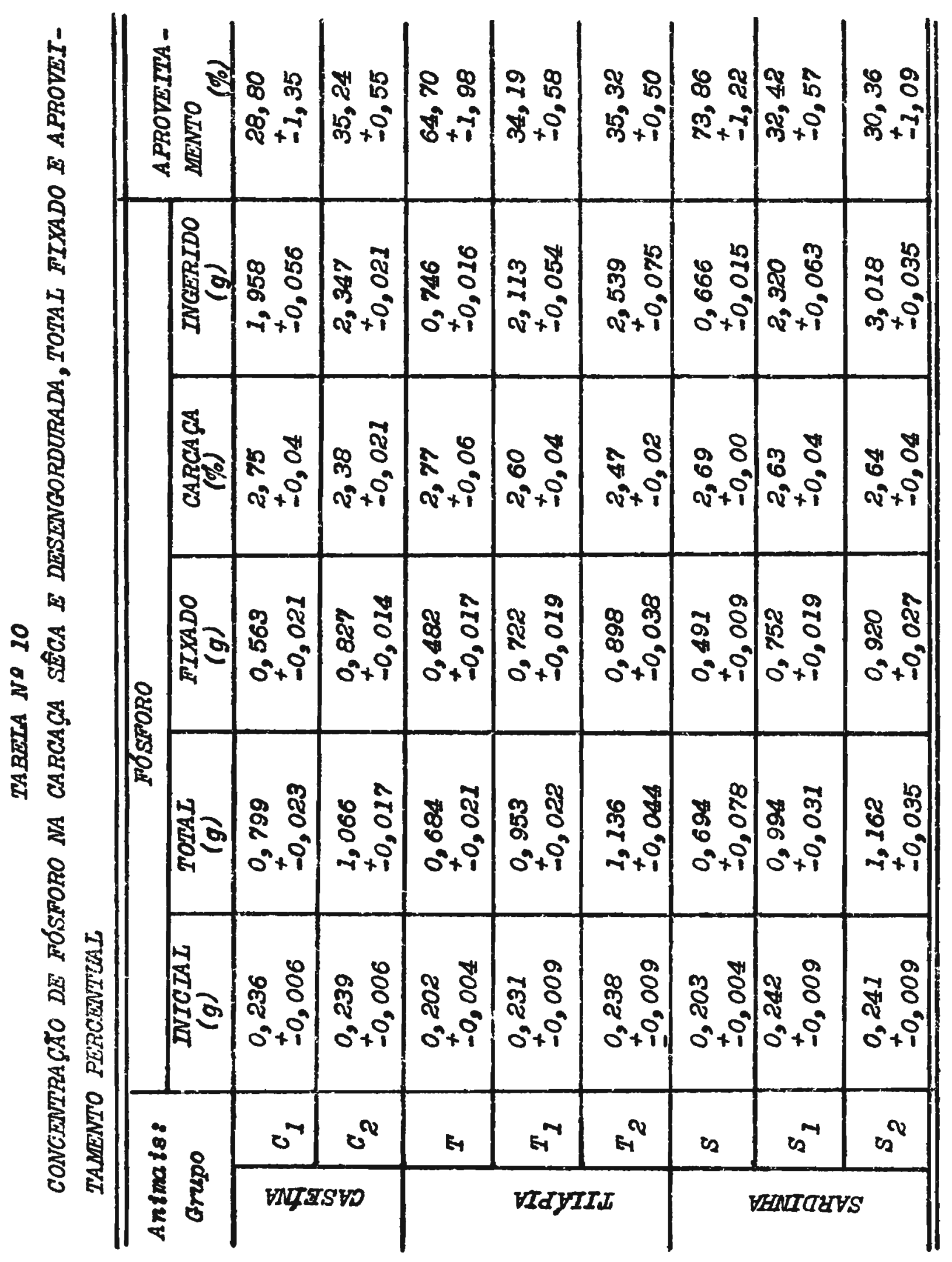




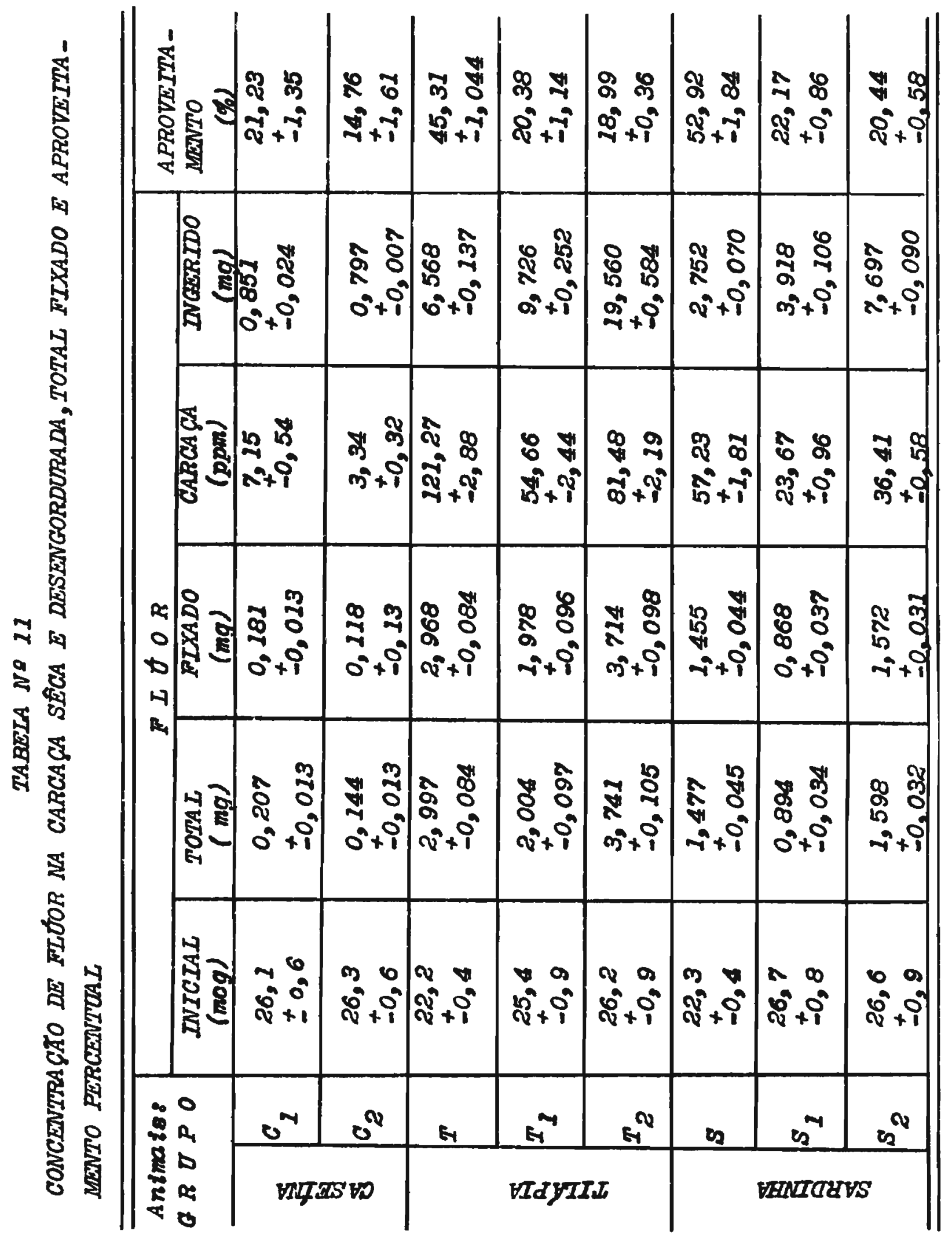




\section{5 - Tabela Geral}

Para permitir melhor comparação dos dados obtidos, reunimos na tabela 12 as informações relativas ao Coefictente de Eflcácta Alimentar e Protéica, bem como o aproveltamento percentual do nitrogênto, cálcto, fósforo e flúor ingeridos. 


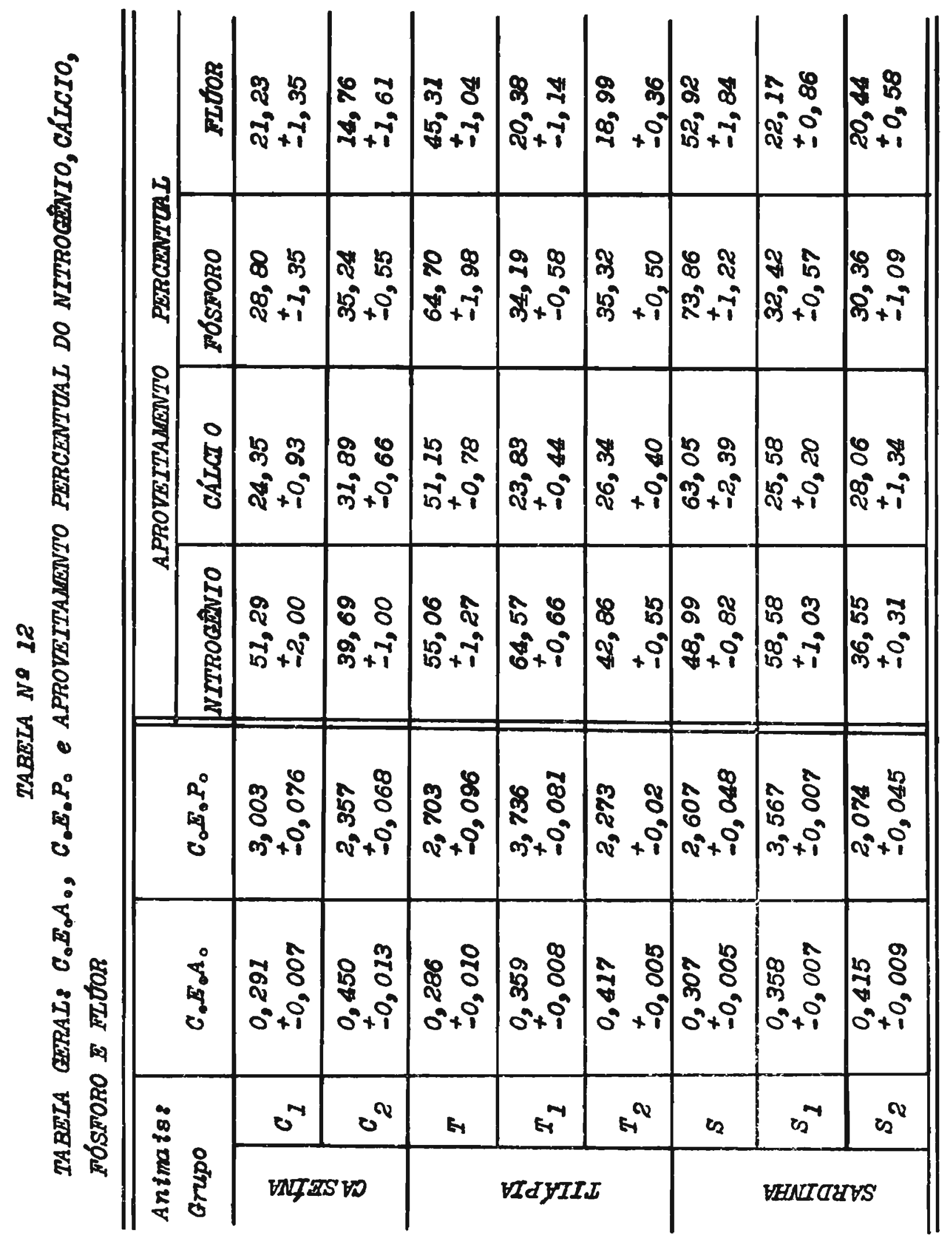




\section{7 - ANALISS DOS DADOS}

\section{2 - Concentrados protétcos}

A compostção centestmal médio dos concentrados mostra a grande riquesa do produto em protefna e minerats, particularmente cálcto, fósforo e flíor (tabelas 2 e 3), sua fração protéica possut todos os aminocicidos constierados essenciats ao organismo humano (tabela 4)

$$
7_{0} 2-\frac{\text { Coefictente de Eficácia Alimentar }\left(C_{0} \bar{H}_{0} A_{0}\right) \text { e Coefi- }}{\text { ctente de Eficácia Protétca }\left(C_{0} E P_{0}\right)_{0}}
$$

A comparagão, através da análise estatistica dos resultados dos grupos $T_{1}, S_{1}, C_{1}$, mostrou haver diferenga signifloativa no consumo de rasão, aumento de pêso, C.E.P. $e$ $C_{0} E_{\circ} A_{0}$ entre os grupos $T_{1}$ e $C_{1} ; S_{1}$ e $C_{1}$. Nấ fol, porém, significativa entre os grupos $T_{1} e S_{1}$.

A comparafão entre os grupos $\mathrm{I}_{2}, \mathrm{~S}_{2}$ e $\mathrm{C}_{2}$ mostrou signiflcância, para o $C_{0} E_{0} P_{0}$, nas diferengas entre os grupos $\mathrm{T}_{2}$ e $\mathrm{S}_{2^{\circ}} \mathrm{S}_{2}$ e $C_{2}$ para o $C_{0} E_{0} A_{0}$, entre os grupos $\mathrm{T}_{2}$ \& $C_{2}$;

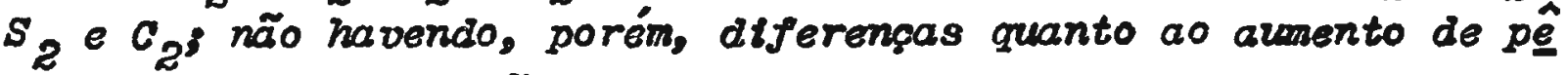
so. 0 consumo de rasão fol diferente entre os grupos $\mathrm{T}_{2}$ e $\mathrm{C}_{2}$ $s_{2} \in C_{Z^{\circ}}$

A comparagão entre 08 grupos $T_{1}$ e $T_{S} S_{1} e$ $S$, mostrou haver diferenga signiflcativa no consumo de ragão, - 
aumento de pêso, C.E. $C_{0} P_{0}$ e $C_{0} E_{0} A_{0}$ Estas diferencas, entretanto, não se manifestaram entre os grupos $T$ e $S_{0}$

08 grupos submetidos às rações (2) $120 \%$ de prote(na) mostraram aumento de pêso e C.E. $E_{0} A_{\text {. significativa- }}$ mente supertores a0s obtidos para 08 grupos correspondentes, sub metidos às rações (1) (10\% de protelna). Entre os grupos (1) e (2) não houve diferença significativa no consumo de ração.

\section{3 - Aproveitamento percentual do nitrogênio ingerido}

A análise estatística do aproveitamento do nitrogênio revelous por comparação dos valores obtidos para os grepos (1) entre $8 i$ e (2) entre $8 i$, bem como entre $T_{1}$ e $T_{3} T_{e}$ $s_{3} s_{1}$ e $s$, serem significantes as diferengas observadas.

\section{4 - Aproveltamento percentual do cálcio ingerido}

A análise estatística do aproveitamento do cálcio nos grupos (1) mostrou ser significativa a diferença entre os grupos $T_{2}$ e $S_{2}$ não o sendo entre os grupos $T_{2}$ e $C_{2}$ nem entre os $S_{2}$ e $C_{2}$

Nos grupos (2), foram significativas as di ferengas encontradas entre os grupos $T_{2}$ e $C_{2}$, bem como $S_{2}$ e $C_{2}$, não o sendo nas encontradas entre $T_{2}$ e $s_{2}$

\section{5 - Aprovettamento percentual do fósforo ingerido}

A análise estatística mostrou ser diferen te o aprovettamento do fósforo nos grupos (1).

Nos grupos (2) foram significativas as $d \underline{\underline{i}}$ ferengas entre 08 grupos $T_{2}$ e $s_{2} s_{2}$ \& $C_{2^{\circ}}$

A comparação dos grupos $T$ e $T_{1}$; $S$ e $S_{1}$, bem como $T$ e $S$ nostrou serem significativas as diferencas obser vadas. 


\section{6 - Aprovettamento percentual do fluor ingertdo}

A anailise estatfstica mostrou que as dife renfas obtidas entre os grupos $T_{1} \bullet T_{1} S_{I}$ o $S$ (submetidos a diferentes concentrafōes de minerals na dieta), foram significat vas, o mesmo ocorrendo entre 08 grupos $S \in T$.

08 grupos submettios d̀s ragôes isominerats mostraram ser significativa apenas a diferenga obeeruada entre 0 aproveitamento do flúor pelos grupos $T_{2}$ \& $S_{z} I_{2}$ \& $S_{2}$.

A conoentragâo do fluor ne carcaga $e$ o to tal fixado, foram diferentes estatisticamente, en todos os grupos, com exceção da diferenga obseruada na concentragão do ha lo gênto entre os grupos $T_{I} \circ S_{0}$ 
8 - DISCUSSATO DOS RESULTADOS

\section{1 - Os conoentrados}

As vartagôes de componentes, observadas nos concentrados de tilápla o de sardinha, mostram alguis as pectos interessantes. Assim, por exemplo, o mator teor de "cinsa" no concentrado de tilápla pode ser explicado pela malor percentagem de oseos na matéria-prima empregada, fato já reforldo por POHBR (78). Essa varlação pode ser também inter pretada como resultado da mator fragmentagão dessas estruturas antes da extração ou curante a pulverização do matertal sêoo | BROWN e col.(5), DE e BANNAM (9) Io A rtqueza em cá1 cto e fósforo decorre, por consequêneita, da proporşão de 08808 - escamas presentes no pó final obtido.

A observacão dôsses fatos é importante, porque ougere a possibilidade de se obterem produtos com maior ou menor teor de un dos componentes, tendo stdo, mesmo, a solução proposta por BROWN e col。(5) para diminuir o teor de flíor de ooncentrados preparados con peixes intelros*.

0 ba ixo teor de umidade e de extrato etéreo indtca a posstbtlidade de boa conservação do produto, qua-

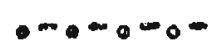

(*) Para atender à exigêno ta do $F_{0} D_{0} A_{0}$ americano. 
Iidade particularmente tmportante em pafses que apresentam con diçoses oltmáticas desfavorívets.

Com relagão ao flíor, notamos ser o concen trado de tllápta multo mats rico que o de sardinha. Neste caso, porém, a diferenga não parece devtia, apenas, à mator percontagem de ossos e escamas no produto, mas, também, à diferente concentraģão do halogênto nos do is petxes.

Análises realizadas em nosso laboratório densonctaram conoentragōes de flíor de até 2300 e 1300 ppm, reg pectivamente, em 08808 e escamas de tilápla, e de 426 e 76 ppm nas meemas estruturas de sardinhas. Verificamos, também, que a ttlápta, desde a fase de alevino (e a partir dat, sempre de forma cresoente*), possut elevado teor do halogênto, auperior ao de autros peixes que vivem no mesmo ambtente, como o corim batá e o blagh-bass.

Os fatos actwa referidos indican que oteor de flúor nos concentrados não pode ser constderado em va lores absolutes: OLIVEIRA (73), por exemplo, encontrous, em fa rinhas de sardinha de consuno antmal, concentragốes de flíor de 50 a $80 \mathrm{ppm}$ em frongấo da época do ano. Nós mesmos, em expertênotas prévias, obtivemos conoentrados de tilápla com 400 ppm e de sardtnha com 130 ppm。

- concentrado de tilápla apresento eleva do teor de ferro, superior aos valores médios de concentrados de outros petxes, fato ilustrado pelo quadro II.

QUADRO II

\begin{tabular}{|c|c|}
\hline CONCENIRADO & $\begin{array}{c}\text { PERRO } \\
\text { (mg/ } 100 \mathrm{~g} \text { de olnzas) }\end{array}$ \\
\hline Ttlápia .............. & 422 \\
\hline Sardinha ................. & 90 \\
\hline$F_{0} I_{0} R_{0} I_{0}(25)$ & 296 \\
\hline$\nabla t o b i n(15) \ldots \ldots \ldots \ldots \ldots \ldots \ldots \ldots \ldots \ldots$ & 287 \\
\hline Bureau of Commerctal Ftshertes (98) .... & 140 \\
\hline
\end{tabular}

- - - - - - -

(*) Dados obtidos em nosso laboratório 
Os produtos por nós obtidos mostram a com posição extgida pela legtslação ma is recente, que $\dot{e}$ a do $F_{0} D_{0}$ A. (98), para êse tipo de alimento apenas o teor do flíor do nosso concentrado fot supertor a 100 ppm, máximo permitido. Visando conhecer a composição da fração protéica dos concentrados, factlitar estudos posteriores rela $t i v a s$ ao uso do produto na suplementacão de protelnas deficien tes, verificar se houve efeito prejudtotal ao produto durante - processamento, determinamos os seus aminoáctdos essenciais.

0 quadro III inclut, para fins de compara são, os aminogramas obtidos por nós e por outros autores. 0 resultado fornectdo pela F.A.O. é o da médta de 38 diferentes amostras de farthhas de peixes.

\begin{tabular}{|c|c|c|c|c|c|}
\hline \multirow[b]{2}{*}{$\begin{array}{c}\text { Amtroactdo } \\
\mathrm{m} / \mathrm{g} 16 \mathrm{~g} / \mathrm{N}\end{array}$} & \multicolumn{4}{|c|}{$C O N C E N T R A D O$} & \multirow[b]{2}{*}{$\frac{\text { Clupea }}{\text { Iongiceps }}$} \\
\hline & Ttlápta & Sardinha & $\begin{array}{l}\text { Orophycts } \\
\text { chuss (99) }\end{array}$ & $\begin{array}{l}F_{0} A_{0} O_{0} \\
(19)\end{array}$ & \\
\hline Isoleuctna & 4,705 & 3,733 & 4,56 & 4,293 & 5,23 \\
\hline Leuctina & 7,296 & 6,050 & 7,78 & 7,214 & 8,29 \\
\hline Ltatna & 8,810 & 7,753 & 8,41 & 7,724 & 9,66 \\
\hline Fent Ia lantna & 3,978 & 3,448 & 4,24 & 3,762 & 3,98 \\
\hline Ttrastina & 3,305 & 3,014 & 3,35 & 3,080 & - \\
\hline Cistina & 1,045 & 0,576 & $0,77^{* *}$ & 1,229 & - \\
\hline Metionina & 2,273 & 2,176 & 3,30 & 2,729 & 3,25 \\
\hline Treontina & 4,528 & 3,581 & 4,47 & 4,229 & 5,85 \\
\hline Triptófano & $1,560^{*}$ & $1,569^{*}$ & 1,03 & $0,957 * *$ & 1,13 \\
\hline Valina & 4,390 & 4,708 & 5,26 & 5,075 & 7,16 \\
\hline Método & \multicolumn{4}{|c|}{ Cromatográfico } & Microbiol \\
\hline
\end{tabular}

(*) Doseamento por método químico

(**)Dosecmento microbiológico 
Os concentrados de tllápia e de sardinha possuem todos os aminocíctios essencia is, sendo que o conterido total dêste é superior no primetro.

- nosso concentrado de sardinha mostra re sultados inferiores aos obtidos por KADKOL e LAHIRI (33), mas é preotso notar: 19) que os peixes pertencem a espécies atferentes; 29) que o processo de análise usado por aquêles autores fol miorobtológtco e o nosso oromatográftico.

o conterido, em triptófano, de nossos concentrados mostra-se, $\grave{a}$ primetra vista, superior (50\%) ao dos ou tros, ao passo que o teor de aminoćctdos sulfurados, espectalmen te 0 de cistina, revela-se infertor no produto obtido da sardinha.

Conhectida a Jabilidade térmica dos aminoá oldos aulfurados |DONOSO e col。(13), SAABBUCETTI e SANAGUJA (81)| $e$ visto que os petxes frescos |FAO (29), FERREIRA e GRACA (21)| apresentam mator teor dêstes aminoácidos, parece-nos ifcito supor que o aquecimento tenha provocado alguma destrutgão dos mes mos em nossos produtos.

Sabendo que o valor blológlco de uma protefna está, entre outros fatôres, na depenciêncta do equidíbrio entre os teores dos diversos aminocictdos essencials, calculamos seu cômputo protétco segunáo o proposto $F_{0} A_{\circ} O_{0}$ (20). Essa operg gâo visou estabelecer a extstêncta de un posstvel fator limitan te $e$ obter uma indicação aproximada do valor biológico da protelna dos ooncentrados de tilápia e de sardinha.

No QuadroIV, apresentamos os valores obti dos, tomando como referênota a protelina do ovo e usando, para o oáloulo, os valores do aminograma do ôvo e da caselna, encontra

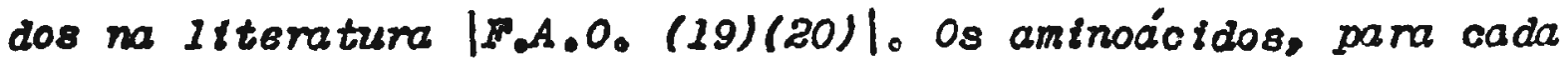
protetna, estão expressos em $\mathrm{mg} / \mathrm{g}$ de nitrogênto e em percentagem. 
QUADRO IV

\begin{tabular}{|c|c|c|c|c|c|c|c|}
\hline & \multirow{2}{*}{$\begin{array}{l}\text { Itiénta } \\
\text { mg/gN } x\end{array}$} & \multicolumn{2}{|c|}{ Sardinha } & \multicolumn{2}{|c|}{ Caoctina } & \multicolumn{2}{|l|}{$\delta_{20}$} \\
\hline & & $n g / g N$ & $\%$ & $n g / g N$ & 9 & $m g / g N$ & 6 \\
\hline Ioolenc ina & $294 \quad 11.20$ & 233 & 10.18 & 345 & 20.76 & 415 & 22.91 \\
\hline Iewoina & $456 \quad 17.40$ & 378 & 16.53 & 607 & 18.93 & 553 & 17.20 \\
\hline Itolna & $552 \quad 22.04$ & 485 & 21.20 & 518 & 16.16 & 403 & 12.40 \\
\hline $\begin{array}{l}\text { Pent la lamina } \\
\text { Tirosina } \\
\text { Aromát toos }\end{array}$ & 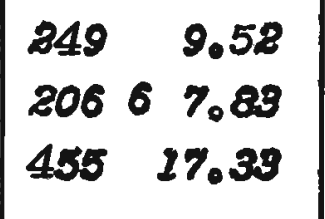 & $\begin{array}{l}215 \\
189 \\
404\end{array}$ & $\begin{array}{r}9.40 \\
8.26 \\
27.64\end{array}$ & $\begin{array}{l}334 \\
371 \\
705\end{array}$ & $\begin{array}{l}20.42 \\
21.57 \\
21.99\end{array}$ & $\begin{array}{l}365 \\
262 \\
627\end{array}$ & $\begin{array}{r}21.35 \\
8.15 \\
28.50\end{array}$ \\
\hline $\begin{array}{l}\text { Ctstina } \\
\text { Metionina } \\
\text { Sulfurados }\end{array}$ & $\begin{array}{rl}65 & 2.48 \\
149 & 5.46 \\
208 & 7.94\end{array}$ & $\begin{array}{r}36 \\
136 \\
274\end{array}$ & $\begin{array}{l}1.57 \\
5.94 \\
7.51\end{array}$ & $\begin{array}{r}23 \\
178 \\
201\end{array}$ & $\begin{array}{l}0.72 \\
5.55 \\
6.27\end{array}$ & $\begin{array}{l}149 \\
197 \\
346\end{array}$ & $\begin{array}{r}4.63 \\
6.13 \\
10.76\end{array}$ \\
\hline $\begin{array}{l}\text { Treonina } \\
\text { Triptofano } \\
\text { Talina }\end{array}$ & $\begin{array}{rr}283 & 10.81 \\
98 & 3.75 \\
275 & 10.50\end{array}$ & $\begin{array}{r}829 \\
99 \\
294\end{array}$ & $\begin{array}{r}9.75 \\
4.38 \\
28.84\end{array}$ & $\begin{array}{l}297 \\
209 \\
430\end{array}$ & $\begin{array}{r}9.26 \\
3.21 \\
13.41\end{array}$ & $\begin{array}{l}317 \\
200 \\
454\end{array}$ & $\begin{array}{r}9.86 \\
3.10 \\
24.12\end{array}$ \\
\hline Total & $2.620100,00$ & 2,288 & 200,00 & 3206 & 200,00 & 3.215 & 200,00 \\
\hline $\begin{array}{l}\text { Cómputo } \\
\text { Protelco }\end{array}$ & 74 & & 9 & & 8 & 100 & \\
\hline
\end{tabular}

Como so podo observar pelo quadro acima, a peraentagon dos amtnociotdos oulfuracios nos concentrados é infe rior a da proteína-padrĩo escolhtda, constituindo-se, portanto,no fator 1 imitante principal.

A existêncta de um fator limitante representado pelo batxo teor de aminoćotdos sulfurados não nos surpreendeus, pots o fato já fôre veriftcado por outros autores I MORRISON \& NO IAUCEAN (62), MORRISON \& SABRY (64), STILLING \& COL.(94), TANDEZ \& DONOSO (102) O TANEZ - COL.(203)1.

Como o cômusuto protéico guaria relagão oom

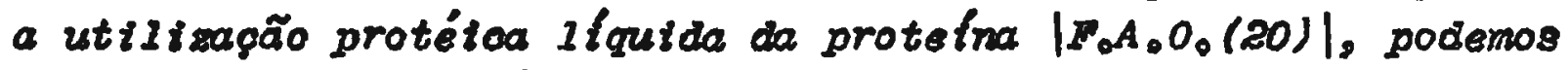
dixsr, com base no oômputo obtido para $0 s$ nossos concentrados, que 
a protefna do concentrado de tilápia deverá ser supertor à da sardinha e, ambas, melhores do que a caselna.

o quadro IV mostra, também, o excesso de lisina em relação à protefna-padrão considerada. Este fato é particularmente importante, se pensarmos no uso dos concentrados para suplementagão de fartnhas de oereals, cuva protefna é defictente nesse aminoćcido.

Se bem que o estudo da compostgão qutmica dos alimentos represente valloso recurso para a indicagão de seu valor altmentar, êle näo dispensa os ensaios btológicos para con clusões definitivas sôbre o assunto. Portanto, com o intuito de obter conhectmentos mals seguros sôbre o valor biológlco dos con centrados protétcos de tilápia e de sarainha, procuramos verificar a uttlisaçäo das sues protefnas por antmats jovens.

$$
8.2-\frac{\text { Bnsalos biológtcos }}{8.2_{0} 1-\frac{C_{0} E_{0} A_{0}, C_{0} B_{0} P_{0} \text { e aprove itamento percentual do }}{\text { nitrogênto. }}}
$$

Como se vertfica pela ourva do pêso (vide página 30 ), o orescimento dos animats, durante a expertência, fot normal, comparável ao de animate de mesma idade. Verificouse, também, crescimento ma is acentuado dos antmats alimentados com as racōes mais ricas em protelna (20\%) e, ao nivel de $10 \%$, raqueles que reoeberam, nas raçōes, suplementagão mineral. If sabtio que antma is alimentados com rafões que possuem $20 \%$ de protetna tendem a ganhar mats pêso $e_{\text {, - }}$ em rungão disso, passam a ter aumentadas as necessidades calór cas, ingerindo mats rasão. Dat resulta, também, un maior coefictente de eficáota al tmentar, se relacionado a rações contendo nívets de apenas $20 \%$ de protetra.

Como já fot descrtto na análise dos dados (vide página 43 ), 0 armento de pêso $e$ o $C_{0} \bar{B}_{0} A_{0}$ dos antma is alimentados com as rą̧óes (2) foram signtflcativamente supertores cos dos alimentados com as ragões (1), como erade seesperar,Quan to ao consumo de ragäo, há, nos grupos $T_{2} \in C_{Z}$ una tendêncta - 
(não significativa) a um mator consumo. No grupo $S_{z}$ em relação a $s_{1}$, inversamente, a tendêncta é para un consumo menor êste, porém, não sendo estatisticamente significativo, não pode ser atributído a nenhuma causa espectfica.

Concentrados de Urophucis shuss, preparados pelo processo por nós uttIizado, sendo testados exaustivamente, não mostraram taxidade |Bureau of Comerclal Flsheries (99)|; também no caso dos concentrados de tilápla e de sardinha, a adí fão de $25 \%$ de concentrados à ração não oausou fenômenos perceptivets de caraiter tóxico.

Para determinar a supertortdade ou não de un concentrado sôbre o outro (ttlápta e sarainha), e de ambos sôbre a casetra, comparamos o orescimento dos antmats seguando o ntoel de protelna recebido na dieta.

Como é sabido, a mator ingestão de rações contendo nlvels baixos de protetna de boa qualidade e balanceadas calórtcamente, corresponde mator aumento de pêso e mator $C_{0}$ $B_{0} A$ 。

Comparando os antmats do grupo (1)entre st, venos que o consumo de ragão do grupo $I_{1}$ fot mator do que $S_{1}$ ( $P$ 0,01), e ambos superiores ao do grupo $C_{1}$, tendo-se verifica do, em correspondêncta, que o C.E.A. dos antmats altmentados com os concentrados era oupertor ao dos antmats alimentados com a ca sefna, o mesmo acontecendo com o pêso da carcaģa sêca e desengor durada $(P<0,01)$. Tal fato indica a supertorldade dos concentrados sôbre a caseína, não se evidenctando, porém, supertoridade de um sôbre outro.

Comparando as mesmos indices com as rações contendo $20 \%$ de protelna, apesar de os ratos submetidos às ditetas de casefna ingerirem menos ração $(P<0,01)$ do que os que a receblam com os concentrados, nâo se vertficou diferenga signtfleativa no pêso da carcaga sêca e desengordurada. $0 \quad C_{0} E_{0} A_{\text {., }}$ porém, fol superior para a racão contendo caselna. Tha vez que as ragôes eram isocalórtcas, êsse fato nos faz pensar numa maior deposição de 1 fptdes na carcaga dos antmats do grupo $C_{2}$ devido à mator efictência calórica dessa ração. Bntretanto, a análise dos Itpties da carcaça dêstes antmats, não permitiu conclusões sôbre o fato.

A determinação do orescimento do antmal $e$ 
do $C_{0} E_{0} A_{0}$ possibilita o estabelectmento de uma perspectiva global sôbre o valor do alimento, enquanto o $C_{0} E_{0} P_{0}$ é rm indtce diretamente relactonado à qualtdade da protelna.

o $C_{0} E_{0} P_{0}$, medtdo ao nível de $10 \%$ de protetna na rasão, nas racỗes balanceadas, mostrou serem as protef nas dos concentrados de qualtdade supertor à da casetna $(P<0.01)$,

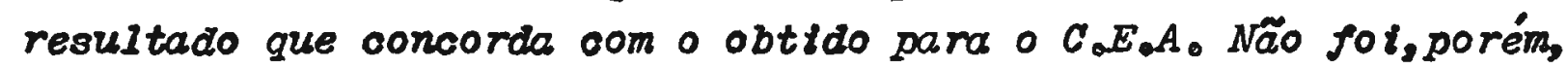
evidenctada, superiortdade stgnificattva de un concentrado sôbre outro, ao nfvel estatfstico registrado.

No Quadro $V$, comparamos os resultados ob tidos pelos nossos concentrados aos dos melhores produtos obti dos e testados en outros palses( paigina segutnte)

Verifica-se, pelo quadro, que os produtos por nós obtidos comparam-se, favorivelmente, aos de outros patses e, também, que a caselna por nós utilizada como padrão é de boa qualidade, comparível à usada por outros autores. Astes re sultados estão, também, de acôrdo com o extgido pela legislação americana para o valor btológtco da protelna de concentrados de petixe.

Comparando as ragões (1) e (2), observamos que, ao contrário do que se passa com o $C_{0} E_{0} A_{0}, O_{0} C_{0} E_{.} P_{0}$ diminut com o aumento do teor de protelna na ragão. Isto confirma a mes ma observacão de outros autores que usaran concentrados protétcos de peixe |MORRISON \& CAMPBELL (61), LORRISON e C01。(65)| e caseína |MORRISON \& CAMPBELL (61)|。

Como a medida do valor biológtoo de uma protelna pelo $C_{0} E_{0} P_{0}$ baseia-se apenas no aumento de pêso, também determinamos a retensão de nitrogênio pelo antmal, a partir do ingertdo. Para êste fim, o exame da carcaça pode dar informagões oôbre a utiliząão protétca liqutda aparente. Aparente, pols a retencão do nitrogênio fot estabeleotda pela diferença entre o nttrogênto final e o intctal obtido do $\omega^{0}$, e não entre - nitrogênto final e o da caroaga de antmats mantidos $80 b$ dieta aprotétoa, noma Imente usada para a determinação da uttlizagão protétca Ifquida |MITLER \& BEWDER (58)|。

Os valores obtidos para o aprovettamento do nitrogênto, comparados aos do cômputo protéico, conftrmam as indicacôes fornectias pela análtse dos aminoáctdos.

No quadro seis (VI), estão representados os valores do cômputo $e$ do aproveltamento do nitrogênto, cál oulados em relagão à coselna fixada como 100 , ilustrando a oor - 


\begin{tabular}{|c|c|c|c|c|c|}
\hline \multirow{3}{*}{$\begin{array}{l}\text { SOLPRHEL - } \\
\text { FROCENSSO }\end{array}$} & \multirow[b]{3}{*}{ PKIXES OIILIZADO } & \multicolumn{3}{|c|}{$C_{0} P_{0} P_{0}$} & \multirow[b]{3}{*}{ REFER } \\
\hline & & \multicolumn{2}{|c|}{ COTCENIIRADO } & \multirow[b]{2}{*}{ CASELNA } & \\
\hline & & QBTIDO & AJUSTAD & & \\
\hline \multirow[t]{2}{*}{ SOPROAADL (SO) } & $\begin{array}{l}\text { Sardinelia } \\
\text { aunta } \\
\text { Itiánta } \\
\text { melanopleuna }\end{array}$ & 3,736 & 3,12 & 3,003 & \\
\hline & Unontrote struge & 3,24 & 2,70 & 3,00 & $(99)$ \\
\hline \multirow{6}{*}{ Ropropanol 170} & toallazsintegrad & 2,76 & 2,64 & 2,60 & \multirow{4}{*}{$\begin{array}{l}\text { (78) } \\
(29) \\
\end{array}$} \\
\hline & $\begin{array}{l}\text { Descabegado e } \\
\text { Sovtoerado }\end{array}$ & 2,68 & 2,58 & 2,60 & \\
\hline & Pllé & 3,09 & 2,97 & 2,60 & \\
\hline & Bacollhar spillé & 3.07 & 3,07 & 250 & \\
\hline & Bacalhau sPllé & 3,80 & 3,12 & 3,04 & (61) \\
\hline & Arenque & 3,21 & 3,09 & 2,60 & $(78)$ \\
\hline Itopropanal (25) & $\begin{array}{l}\text { Bacalhau(restda) } \\
\text { Arenque (reafda) }\end{array}$ & $\begin{array}{l}3,01 \\
3,23 \\
\end{array}$ & $\begin{array}{l}2,58 \\
2,76 \\
\end{array}$ & $\begin{array}{l}2,88 \\
2,88 \\
\end{array}$ & (62) \\
\hline ETANOLL (37) & Grínea Iongteer: & 2,92 & 2,40 & 3,04 & (8y) \\
\hline EXANOL (103) & Merincating onut & 2,74 & 2,74 & 2,50 & (29) \\
\hline \multirow{3}{*}{ f, 2-D1010 ro dtoro } & & 3,20 & & & (24) \\
\hline & & 2,63 & 2,48 & 2,65 & \multirow{2}{*}{ (32) } \\
\hline & Sardinina & 2,70 & 2,55 & 2,75 & \\
\hline 2- BOTHWOL & "Menra dem" & 3,05 & 2,59 & 2,98 & \multirow{2}{*}{ (62) } \\
\hline $\begin{array}{l}\text { I, 2-Dicloroe- } \\
\text { tano-Vtobli }\end{array}$ & Itotode vírtos & 2,52 & 2,13 & 2,92 & \\
\hline
\end{tabular}

Valores ajustados para caselna $=2,50$ 
respondêncta extstente. Isto confirma a supertoridade dos concentrados sôbre a caseina e permite constderarmos o concentrado de ttlápla supertor ao da sardinha, superioridade que o $C_{0} E_{0} P_{0}$ não evtdenctara.

\begin{tabular}{|c|c|c|c|}
\hline \multirow[b]{2}{*}{ METODO } & \multicolumn{3}{|c|}{ FONIE PROTEICA } \\
\hline & CASEINA & SARDINEA & TILA'PIA \\
\hline COMPOTO PROTEICO & 100 & 119 & 227 \\
\hline APROVEITAUENTO \% do $N^{*}$ & 100 & 114 & 126 \\
\hline
\end{tabular}

* Para $10 \%$ de proteína na racão.

Devemos salientar, ainda, a importânota que o nf́vel de proteína na ração e o método utilizado assumem na avaltafão do valor blológtco dos concentrados, evidente pelos resultados obtidos para o $C_{0} E_{0} P_{0}$, e aproveltamento do Nitro gênto nos vários grupos experimentats.

\subsection{2 - Aproveltamento dos minerais}

Paralelamente ao conhecimento do valor blológico da proteína dos concentrados, procuramos obter infor mações sôbre a eficáota dos minerats na manutenção do crescimen to e, especialmente, a utiliaação do cálcto, fósforo e flíor particularmente dêste último, pela ambivalêneta de seus efeftos. Com essa finalidade, obtivemos os mesmos indices $\left(C_{0} E_{0} A_{0}, C_{0} E_{0} P_{0}\right)$ já discutidos, com antma ts submetidos a ragões sem suplementação de mistura salina, sendo os concentra dos, portanto, a íntea fonte de proteinas e minerals.

o batso teor de minerats - aquém do ótimopresente no ragão, permitiu avalfar a possibtlidade de seu aprovettamento e a constatą̧ão de suas possfveis defictências qualitativas e quantitativas, à vêzes não evidenctávets nas concentra cões normalmente ut 1 izadas.

Comparados os efettos das rafões $I$ e $S$ com as correspondentes $T_{1} \in S_{1}$ verificamos que o aumento de pêso, - 
conouno de ragão e pêso da carcaģa sêca e desengordurada foram otgniffoat tumente infertores $(P<0,01)$ nas ragões não suplemen tadas. O mesmo aconteceu com relagão ao $C_{0} E_{0} P_{0}, C_{0} E_{0} A_{0}$ e retengão do nitrogênio $(P<0.01)$ 。

Tais resultados falam em favor de una deflotêncta quantitativa de un ou mals minerats, ou de sua deficlente ut l1tragão pelo organismo.

JAFYSE (32) e SURE (97) não notaram deftctênctas minerais nos concentrados por êles analisados. 0 primetro, porém, forneceu aos ratos misturas de milho motio (80\%), com concentrado da Vtobtn (20\%)- mator teor mineral, portanto, do que em nosso caso. Além dtsso, JAFH's não determinou o teor dos minerats do milho e do concentrado; o crescimento dos antmats fol comparado ao de outros alimentades com ragão comercial (Purinalo outrossim, nẫ forneceu informagões sôbre o peixe empregado.

SURT (97), estudando dois produtos (Chile no e da Viobin), também não percebeu defictênctas minerats evidenctadas pela comparasão do crescimento de antma is alimentados com casefina e mistura saltna de boa qualidade, com os alimentados com as rasões balanceadas en que o teor de minerals era de $4 \%$.

Bm ambos os casos, é possível que alguma defictência possa não ter stio evtdenciada, devido ao elevado teor de minerals da ragão.

A anélise dos dados obtidios a propósito do aproveltamento do cálclo e do fósforo mostra que a menor teor dêsses minerats na ragão corresponde maior retengão percentual em relagão ao ingertio. Iato é de se esperar, em se tratando de boas fontes, sugerindo uma boa absorgão dos mesmos. similarmen. te, os antmats alimentados com a naqão $s$ mostraram retengão maior do que os que tingertram a ragão $T(P<0.01)$.

A fonte mineral, nos grupos $C_{2}$ e $C_{2}$ era apenas mistura salina; nos grupos $T_{1}, T_{2} S_{1}, S_{20}$ era constitui da por nivets menores de mistura salina e pelos minerats formectios pelos concentrados (Quadro I)。

Comparando o crescimento dos antmats $e 0$ aprovettamento do cálcto e fósforo entre os grupos $c_{1}$ e $c_{2}$ e os outros cttados, podemos dizer que os concentrados são fontes aceitáveis para suplementagão de dietas deficientes nesses elementos。 
Esta possibilidade já fol verificada, no homem, por vários autores, como PRETORIUS WEHLYMEYER (80), SHA PIRO \& C01.(85), SHURPALEKAR e C01.(86) e SPENCER \& C01.(91), que estudaram, especificamente, concentrados de sardinha.

Os resultados obtidos para a retengão do cálcto e do fósforo nos grupos $T_{1}$ e $T_{1} S_{1}$ e $S_{\text {, compa rativamen- }}$ te, não parecem indtcar que tals elementos sejam os responsávets pela deflctêncta mineral obseruada, parecendo que o menor total fisado nos grupos $I$ e $S$ seja devtdo ao menor orescimento causado por algrwa outra defictêncta, ou ao menor pêso tntctal dos a ntmats.

Esta constatação, bem como a observação de sinats de alopecta e o menor teor lipldico encontrado nesses gry pos, Ievaram-nos a dosar o teor de potássto nos concentrados. Os resultados obtidos (vide tabela 2) mostram que, de fato, os teo res de potássto se apresentaram batxos, parecendo indicar que êsses produtos não são boa fonte dêste mineral.

Tal htpótese encontra apoto no trabalho de DU BRUYN \& DREHER (17), que observaram que a suplementação com potássto acarreta desaparectmento das deftctênctas dos antma is alimentados por concentrados da PIRI (rações contendio 4, 4\% de minerais)。

Bntre os minerais presentes nos concentre dos de peixe, já salientamos a importâncla que tem o flíor como micronutriente attvo no prevenção da cárie dental. Asstm, os con centrados passam a ser tmportantes como fonte natural do halogh nto. Como fot discutido antertormente, o teor de flior, espeotal mente no concentrado de tilápla, é elevado, e os valores por nós obtidos são comparáveis aos apresentados por outros autores em concentrados de peixes integrats |CBAYET (7), DREOSTI (16), BHADJIMARKOS (27), OLTVEIRA (73) \& ZIFKDN \& COI。(205)1。

A fisergão nos ossos, do flíor contido nos concentrados, bem como a extensão dessa flxagão é que vão dizer dos efettos do halogênto sôbre o organtsmo. Asstm, procuramos deteminar êstes dots parâmetross o resultado obtido revelou que o fluior dos concentrados se fixa no organismo, como é demons trado pelo mator teor do halogênto nos antmats que ingertram con centrado, em relagão, não só à quantidade de fiúr que extstia no comẹgo da experiêncta, mas tambén em relaçäo ao total fixado nos animats submetidos às racôes-padrão. 
Essa posstbtlidade de fixafão permite explicar, pelo menos em parte, o efetto antioartogêntco dêsses pro dutos, demonstrado por CHA YETT (7), NIZEL \& Co1.(71), OPUZINSECA (74) \& STEFHEN (92) (23)。

o aprovettamento do flúor, entretanto, $\dot{e}$ pequeno, uma vez que apenas cêrca de $20 \%$ do ingerido (a partitr das dietas toominerats) fol rettdo.

LEE e NILSON (44) obtiveram, para o aprovettamento blológtco do fitior contido no salmão, os valores de 29, 75 e 20,25\%, e para o da cavala, 21,47 e 24,4\%, en racôes que continham respectivamente, 5,8 e 19,3 ppr de flior do primetro petxe e 27,0 e 84,5 ppm do segundo. 0 aprovettamento do flúor de consentrados de Urophyeis elpuss, encontrado por ZIFKIV \& Colo (105), fot de 24, 17 a 13\% para ragöes contendo, reopectivamente, 23, 50 e 80 ppmo

Os resultados por nós obtidos conftrmam os dêsses autores, quando comparados nas mesmas concentracões de Jlúor na ragão.

Pelos resultados de ZIFKIN \& Colo(105), ve mos atnda que, com o aumento do teor de flíor na ragäo, há uma diminatgão do aproveltamento percentual. Já LXK \& NILSON (AS) encontraram relapão oposta. Os nossos resultados parecem concor dar com os de ZIFKIN \& Colo, apesar de serem signtficativas ape nas as diferengas entre os grupos $I_{2}$ e $T_{1}$ e $I_{2}$ e $S_{1}$ 。

Constderando que as atetas utilizadas por nós e pelos autores oftados continham alto teor mineral, medimos o aproveltamento do firior também nas racões $T d e s$ os resuf tados obtidos mostram que a utilizagão do halogênto é stgntflca tivanente superfor $(P<0.01)$ àquela obtida com as ragôes $T_{2} e$ $s_{2}$ observa-se que ao menor conteúdo mineral da rasão oorrespon de un mafor aproveitamento percentual. Naturalmente, nas rạões I e $S$, comparadas com $T_{I}$ e $S_{1}$, houve diminutgão dos minerats to tats e nâo apenas do cálctos mas, tendo em otota prinotpalmente

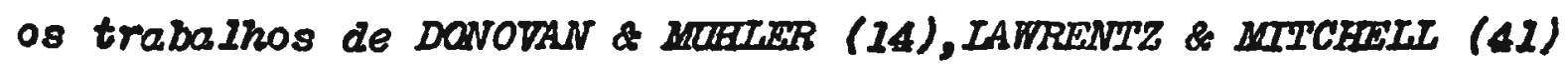
(42), STOOKET \& Co1.(95)(96) e RAGNER E ITUEWER (100), parece if cito suppor que êsse efelto se deva,princtpalmente, do menor teor daquele elemento.

A supostgão actma levantada se fortalece pelas expertênctas de PEILRS (75) e SPENCER (90): o primetro en controu batsa utilização do flúor do lambart (6\%) em nasōes que 
continham elevado teor de cálcio, enquanto que a alta fixacão (50\%) encontrada pelo segundo, a partir do mesmo concentrado es tudado por ZIFKIN \& Colo(105), pode ser atributda ao batxo teor mineral (de cálcto) da dieta.

Procurando, ainda que 1 imitadamente, quantificar a fixagão do halogênto, estabelecemos, a exemplo de Poun CHET-CAMPOS(77), zama curva de regressão, relacionando o flúor na carcaça, com a sua concentração nas racões fornectalas aos antmats.

IJssa curva, com $99 \%$ de probabilidade, pode ser representada peIa equagão.

$$
Y=0.0672 X+0.262,
$$

onde $X$ representa o teor de flúor na ragão (ppm) e $Y$ e flúor fi wdo em mg. Naturalmente, essa equagão só é válida para os teores de minerats por nós ut 11 tmados (raçôes balanceadas $T_{1} S_{1} T_{2}$ $s_{2}$

Supondo-se um consumo diário de $20 \mathrm{~g}$ do concentrado, terfawos a ingestão de cêra de $4,6 \mathrm{mg}$ de fiúor a partir do concentrado de tilápia e de $1,6 \mathrm{mg}$ a partir do de sar dinha. Tendo en vista o aprovettamento obtido, o efetto biológi co deve ser constderado cinco vêzes infertor ao que seria propor cionado pela dose nominal (correspondente a $0,960 \mathrm{mog}$ de flúor). Constderando como wílido que o aproveitamento da flúorapatita é 50\% menor que o equivalente de fiúor como NaP IJACKSON \& Col. (31), ARGENT \& HLTROTH (39) e 10 CLURE \& Cola (50)l, podemos a in da adinttir que a quantidade de flúor, nos concentrados, oorrespon de à metade dessa dose en NaP. No caso da tilápta, a contributsão do concentrado corresponderia, portanto, a $2,3 \mathrm{mg}$ de fiúor como NaP. Diante dos trabalhos de ve CLURE \& Col. (50), podemos dtzer que essa dose não causarta i esmalte manchado, sendo maior a fatsa de seguranga para a sardinha.

Por outro lado, constderando-se a ingestão de dietas pobres en minerals, as doses actma seriam dobradas,parecendo apresentar riscos,apenas em regióes cuja água de abas tectmento contenha altas concentracōes de flúor e batxa dureza.

Pelo menos no caso das dietas normats, não nos parece haver necessidade da recugâo do teor de flúor nos concentrados para que possuam até 100 ppm, conforme extge o - 
F.D.A., uma vez que tsto acarretarta, de um lado, diminutção de nutrientes essenciats (oálcto, fósforo) e, por outro, dimtnutఢ̧ão também da efictêncta antt cartogêntca representada pelo ha logênto, elemento que, por sua tmportância, fot recentemente con stderado como micronutriente essenctal (70).

Os concentrados protétcos, de alto teor em amtnocictdos essenciats, superiores à casefna, ricos em minerais, além do seu já analtsado valor nutricional, apresentam-se com proprtedades organolépticas bastantes favorávetss sua côr é clara, são tnodoros e insfptdos. Em teste-ptlôto, foram preparados pães, cufa acettagão indicou a possibilidade do uso dêsses prodü tos como suplemento alimentar, o que os inclut entre as possivets solucōes, ou atenuantes, para o problema da fome e desnutrig̨ão. 


\section{9 - CONCLUSOES}

9.1 - O uso de isopropanol para a destara tação desengorduramento e desodorização de Sardinella aurita $e$ de Tllápla melanopleura permttiu a obtengão de concentrados protétcos com boas caracterfsticas organolépticas (tnodoros $e$ insf(ptdos).

centrados revelous

$$
9.2 \text { - } 0 \text { estudo bromatológico dêsses con- }
$$

\section{I-Queanto à compostcâo}

1) São ricos em protefna (80\%) ssua fração pro tétca contém todos os amtnoáotios essenciats, apresentando como fator 1 imitante principal o batxo teor de sulfurados. 0 batxo te or de umtdade e Ifpides fala en favor de sua boa conservaçao.

2) Sâo ricos em minerats (10\%), principalmente em oáleto, fósforo e fiúr, devtdo à tnolusão de ossos e esca mas.

310 concentrado de tilápla é rico em ferro, possutndo cêrca de $50 \mathrm{mg}$ por $100 \mathrm{~g}$ do produto.

$410 s$ teores de fluior são de 279 ppm no concentrado de tilápta e $82 \mathrm{ppm}$ no de sardinha.

5) Säo pobres em sódto e potássto. 


\section{II - pranto ao nestor btolóateo}

110 cômputo protétco, caloulado em relação à proteina do ôvo, fol de 74 para o concentrado de tilápia e de 69 para o de sardinha, mostranio correlagão com o aprovettamento percentual do nitrogênto. caselna.

2)A proteína dos concentrados é superior à

3) Considerando os concentrados de tilápia e de sardinha do ponto de vtsta protétoo, aquêle tem superiortidade sôbre êste.

4)Não são fontes completas de minerais, capazes de suportar o crescimento de animats jovens, exigindo suplemen tagão com misturas saltras.

5)A suplementagão dos minerats dos concentra dos, com mistura salina em dots $n$ fvets, mostra ser satisfatória na manutengão do crescimento.

6) oferecem bom aprovettamento de cálcto e

sósforo.

V) aproveltamento do fiúor, a partir de ragoês normate,fol de cêrca de 20\% mantfestando tendência a diminutr com aumento do teor do halogênto na ração.

8) Nâo parece haver necessidade de redugão do teor de flíor dos concentrados, já que seus efeltos btológtcos cor respondem a $2 / 5$ dos da dose nominal, sendo o aproveltamento rungäo do teor de minerats na dieta.

$9 / 0$ flíor fisado na carcaca em $\mathrm{mg}(Y)$ pode ser expresso em rungão da sua conoentração na rasão, em ppm $(X)$, pela equagão $Y=0,0672+0,262$. 


\section{BETERTANCTAS BTBLTOCARAPICAS}

1- ALCAREZ-BAYAN,A. - Composttion and btological qual tty of di-

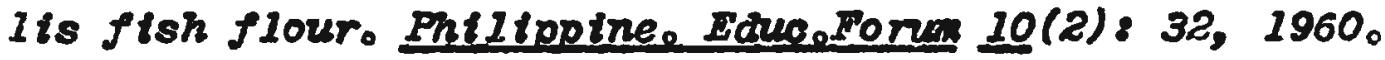
A pud. Chensobstres Columbus, Ont0,57: 14.2480, 1962。

2- ASSOCIATION OF OFFICIAL AND AGRICULTURAL CHWHSTS.-Offictal Wethods of Analysis, $10^{\text {th }}$ ed., Washington, $D_{0} C_{0}, 1965, p_{0}$ 7 5-786.

3-BASU, $X_{0} P_{0}$ et alti - Studies in human nutritton. $\nabla_{0}$ The bones of small fish as a source of nutritionally avatlable calc tum and phosphorus. Indian JemedeReses Calcutá, $30(3)$, 117-122, 1942。

4- BENDER, $A_{0} E_{0}$ \& BAIZELDEN, $S_{0}-$ Btologteal value of the protelis of a varlety of ftsh meals. Br.Jollutre Cambridge, $11(1)=42-43,195 \%$

5- BRONN,No et alit - Studies on the fluorlde partition in fish |comantcapão pessoal|

6- BUITNER, $W_{0}$ \& WOHWER, $J_{0} C_{0}-$ The effect of a diet composed of barley and fish meal on dental carles in rats. Jodent,Reso Baltimore, 37(3)\& 419-421, 2958。

7- CHA YET, $C_{0}$ et altt - Efecto de la hartna de pescado de consumo homano. (Unicef-Chtle-Quintero) sobre la cartes experi mental en la rata blanca. Nutrición Bromatole Toxtcol. Santiago de Cht le, 5(1):20-24, 1966。

8- $D E, H_{0} N_{0}-A$ note on the relative nutritive value and the total and "avallable" methtonine, Tryptophane and histidine in some fish flours. Paktstan J.ScteindeRese, Karacht, G: $^{\circ}$ 299-301, 1963。 
9. $D E, H_{0} N_{0}$ \& BRWWAH, A.- Plsh glour its bloohemical and nutrtttonal studies. I. Field and oremical oomposition of $\mathrm{ftsh}$ protein ooncentrate (FPC) and $f$ ish meal (FW) prepared from vartous fresherter fish of East Paktstan by applicg tion of improved teohntques-SateRes, (Decoa, Paktstan) (3): 85-28, 1965.

20-Di, $B_{N_{0}}$ et altt - Dtsh Flour. Btochemical and witritional studies. II. ot lltzation of proteln of fish flour or ftsh protetn concentrate (FFC) under different dietary level in body protein synthests and fat depostition in relation to growth of tmmature and adult. rats, Sateiles, Dacca, Pa

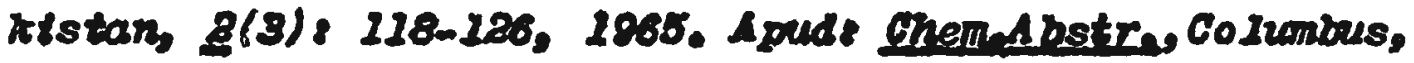
onto, $5.580588 \mathrm{fg}, 1906$.

11-D, $H_{0} N_{0}$ et altf - Fish flour. Btochemical and nutritional studies. III.- Protein efficient ratio value of some fish protein concentrete (JFC) or fish flour and fish vermicel 1t. and influence of decomposttion of fish on the above ualues-SaleRese (Dacoa, Paktstan) 813). 187-134, 1905. A

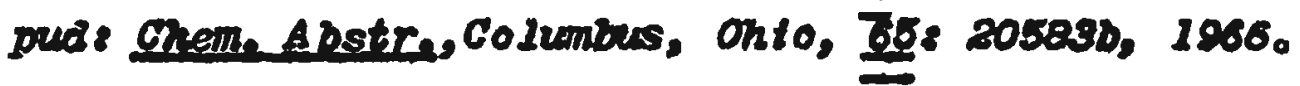

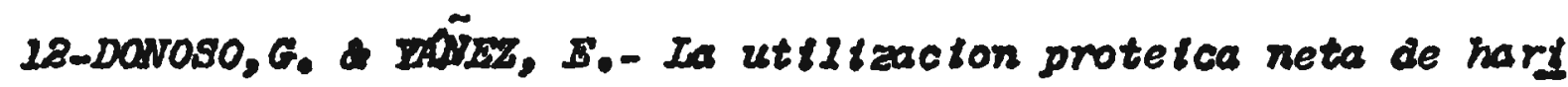
nes de pescado de consumo humano y antmal fabricados em Cntle. Butrtelón: Brozatele Poxteoles Santiago de Chile, $\underline{1}(8)$ \& $97-105,2968$.

13-DaNOSO, 60 et allt - Bffect of heat treatment on the nutrittve value of protetnssohemical and balanse studies-josete

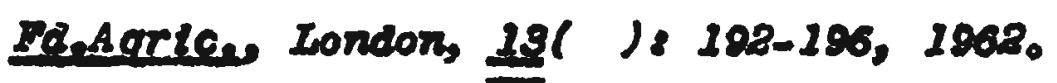

14-DOWOVAN,A.W. LULWW,J.C.- The effeot of inorgantc salts -

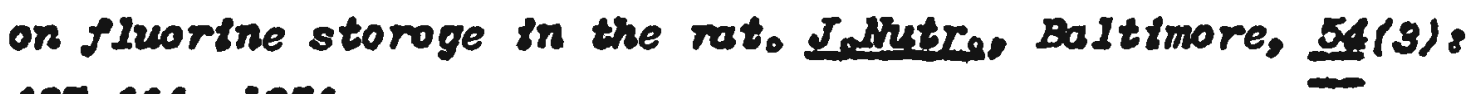
437-ces, 1054.

15-DREOSTI, $G_{0} W_{0}$ - Itsh flour. Teohnologtcal developments in -

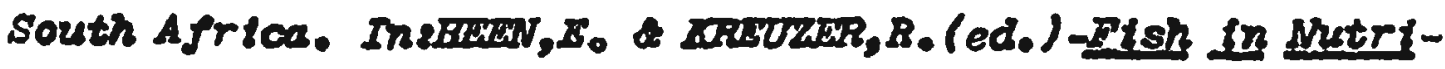
tton, Iondon, Ftshing News (Books)Ltd., 1068, p.425-431. 
16-DREOSII, G.M. - The role of South Afrtcan fishing industry in feeding the nation. SAframedicta Cape Town, 38:631-640, 1964.

17-DUBRUZN, $D_{0} B_{0}$ \& DREYLR, $J_{0} J_{0}$ - studies on the nutritive calue of the mineral components of a South Afrtcan fish flour, with spectal reference to the effect of supplementation with potassizen. ProcelutreSocis.Atres Pretoria, 2859-68, 1961.

18-P.A.O. NOIRITION DIVISION - The use of fish flour as meman food - Prosulutr, Soces Cambridge, 17(8):153-160, 1958.

29 POA.O.NVIRITION DIVISION_FOOD COMSUMPIION AND PIANNING BRANGR-Amine acids contents of foods and blological dato on proteins, Rome, 1968, 280p.

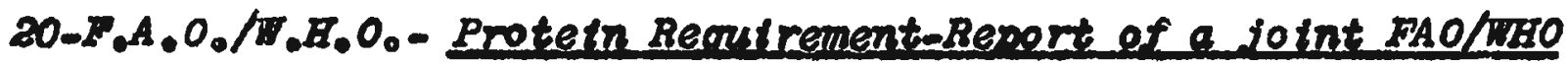
Expert Grove, Rome, 2965 13AO Mutrition Meeting Report Se ries, ne 37, WEO Techntcal Report series, ne 301.1

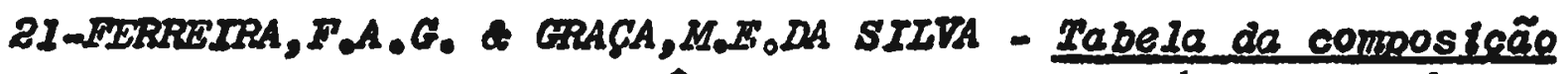
de alimentos portuquêses. Itsboa, Mintstérto da saúde e Asststêncta, 1963, $186 \mathrm{p}$.

22-WHRRO, $P_{0} V_{0} A_{0} S_{0}$ \&AM, $A_{0} N_{0}$ - Colortmetric determination of cal ctron by chlorantitc actd.II.A semimicro method with recu-

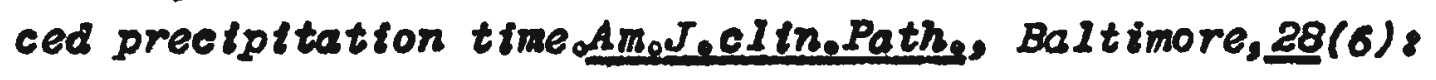
689-698, $195 \%$.

23-FISKE, $C_{0} H_{0}$ \& SUBAROW, $V_{0}$ - The colorimetric determination of phosphorus. JeBtel. Chemes Baltimore, 66(2) \&375-400, 1925

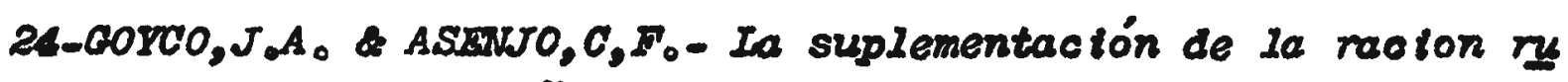
ral puertorlqueña com proteina de pescado. Arehos LatoAmer.Nutres 17(3):241-251, 196\%。 


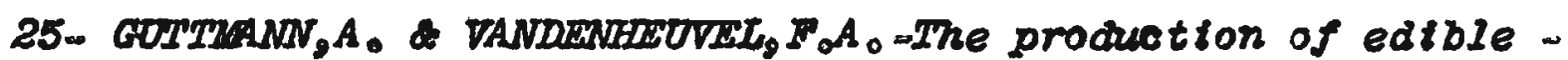
fish protein ("Fish flour") from cod an haddock-PtshoRes. Bd.Canada Proq.RedeAt lant.Coast St.NO 67829-31, 1957.

26- BADTIAREOS, $D_{0} M_{0}-F t$ sh flour and flwortde-sctence, New York, 152(3729) 150\%, 1966。

2\%- HADIMARYOS, D. $K_{0}$-Finortde in fish flour-effect on teetho $J_{0}$ Pedtat.St.Louts, L0, 65(5):782-784, 2964.

28- BARVLY, $W_{0}$ - Fluortne in fish pastes-Nature, London, 155(3928): 175, 1945 。

29- $H O W E_{0} E_{0} E_{0}$ et alil - Amtno actd supplementation of protein concentrates as related to the world protein supplyoje clinellutr, Allentown, 16(3): 321-326, 1965。

30- JACKSON, $D_{0}$ \& WEIDWANW, $S_{0} M_{0}$ - The relationship between age and the fluorine content of human dent in and enamel. A

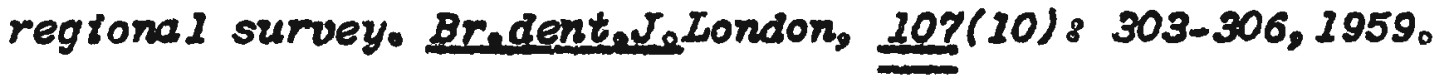

31- JACKSON, $S_{0} B_{0}$ et alit - The retention of fluoride when fed as bone and as sodium fluortde. Jolutre, Baltimore, 40 (4): $515-535,1950$ 。

32. JAFFH, WOGO- Nuevas observectones sobre el valor nutritivo de la hartina de pescadio $y$ su efecto suplementario sobre harl na de trigo y pan-Amahos Fenezolutr, Caracas, 11 (2):191204, 1961 .

33- KADKOL, S. $B_{0}$ \& LAHIRI, N. $I_{0}$ - Amino actd composition of defatted fish flour from otl sardine (Clupea lonqiceps), $J_{0}$ sctent, tnd,Res, New Delhi, 21 D (10): 387-388, 1962.

34- KNOBL $J r_{0}, G_{0} M_{0}$ - The fish protein concentrate story-4. World efforts toward FPC-FC.Technol, Champatgn, 21 (8):11081110, 1967. 
35- KONIVG,A OJ \& MC MULLAN, $X_{0} B_{0}$ - Phospoliptds of marine ortgtn。 III- The ptlohard (S,ocellata) with particular references to oxtdation in pilchard meal manufactureatesct. BdoAarices London, 17(8): 385-388, 1966。

36- IURTZMN,C.H. et alti - Iffect of several processing variables on the protein content and qualtty of fish flour. In BWrat, $\Sigma_{0}$ \& BREUSER, $R_{0}(e d)$-Fish in nutrition, London, Fishing News (Books) Ltdo, 1962,p.228。

37- IAHIRY, $N_{0} L_{0}$ et alti-Preparation of edtble fish flour from ot1 sardine (Clupea longiceps), IdnSat, Mysore,11(2): 3739, 1962,A pud 2lut tr, A bst,Rev, A berdeen, 33 (1) : 91, 1963.

38. IAJOLO, $F_{0} M_{0}$ et altt -Influêncla da côr no consumo de racoês por retos oReve Pace Parm.BtequtmeSoPaulo , 7(1),1969.No pre10

39- IARCERT, $E_{0} J_{0}$ \& HETROTH, $F_{0} F_{0}$-The absorption and excretion of fluorides III.Purther observations on metaboltsm of fluorides at high levels of intake.Jeind Hivaloxicol, New York, 31 (3): 134-188, 1949 。

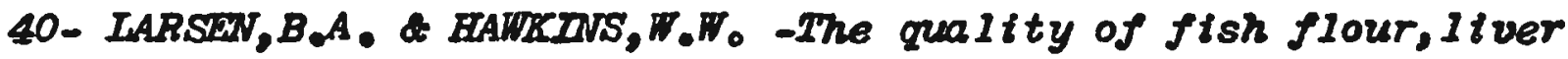
meal and visceral meal as source of dietary protein a FishaRes,BdeCane, Ottawa, 18 (1):85-91,1961。

41- LAWRER8, $M_{0}$ \& MITCHELL, $H_{0} H_{0}$-The effect of dietary calctum and phosphorus on the assimilation of dietary fluortine. Nutr, Baltimore,2Z(1):91-101,1941

42- IAWRENZ, $M_{0}$ \& MITCHELL, $H_{0} H_{0}$ - The relattve assimtlation of flup rine from fluortine-bearing minerals and food (tea) and from water and food.J,Nutr, Balt tmore, 22(6):621-631, 1941 。

43- IBA, $C_{0} H_{0}$ et alt: -Chemtcal and nutritional changes in stored herring meal.2.BroJellutre, Cambridge, 14 (2) : 91-113, 1960 
44- IXES,C.F. NIISON,H,H.- Study of the metrbolism of naturalIy occuring fluortne in canned salmon and mackerel. Was-

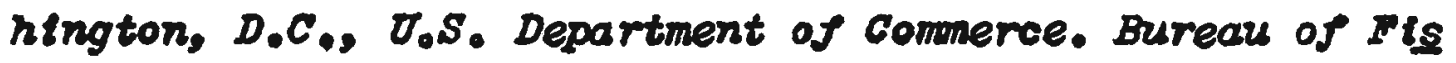
herles, 1939, 15 p. |Investigational Report ne 44 |

45- LEVERTON, $R_{0} M_{0}$ \& PAYAITAL, S.M. - The phystologtcal avatlabt1tty of calctum, phosphorus and nitrogen from the bones and Ilesh of dilts, a small fish used in Filipino diet.phl1lpptne JuSces Mant 10,80: 23-32, 1951. Apeud Nutrabstre Reva,Aberdeen, Z2(1), T75, Abstr. 898, 1952.

46- LEVIV,I. - Fish flour and fish meal by azeotropte solvent processing Pd.Technole, Champatgn, 13(2), 132- 1959.

47- LOVRRR, L.A.- General outlook for edible fish protetn concen trates. In AITSGHU, $A_{0} M_{0}$ - World protein resources. Washington D.C., Amertoan Chemtoal Soctety, 1966,p.37-51. |Advances in chemistry series. 57. |

48- IC LURE, Fo.J.- Fluorine in foods-survey of recent data-Publ. Elth,Repe, Washington, 64(34):1061-1074, 1949.

49- WC LURB, W.J.- Plworine in food and drinking water-Dental health benefits and phystologic effects.J.Amedietedsse, Baltimore, 29(6) :560-564, 2953 。

50- $M C$ LURE, F.J. et alit - Balances of fluorine ingested from ug rious sources in food and water by five young menoExcretion of fiuorine through the skin. JeindeFug. Toxtcol, New York, 27(6): 159-170, 2945.

51- 2ANTIIL,No - Rapid estimation of standard error of means for small samples. Amestatisme, 5:26-2\%, 1951.

52- $\triangle A R C H, B_{0}$. et alti - Composttion and nutritive value of meals

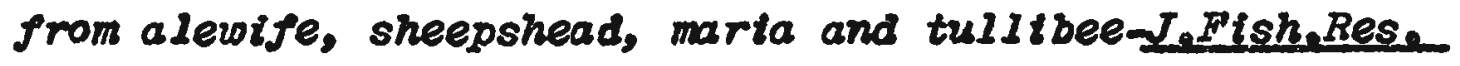
Bd.Can.s Ottawa, 2A(6): 1291-1298; 1967。

53- $14 A I E R, J . R_{0}-$ Muortde research (meeting)。 Sclence,New York, 159(3822) 1494-1495, 1968 . 
54- MASTER, I, \& SGHOUR, I. - Relation to endemtc dental fluorosis to malmutrition. InAli.dentalss, Chicago, 44 (2) : 156-165, 1952。

55- MACROIAN, $S_{0}$ - Rapid spectrophotometric determination of fluo ride with afrcontum-eriochrome-cyantne $B$ lake. Analuts. Ghence Baston, 26(7): 1161-1166, 1964。

56- AMYMA, $V_{0} C_{0}-A$ study in improoing Dast Indian diets Nutritio nal value of Pish flour supplements a InAm Dfet. Assoes Bat timore, $37(3): 234-240,1960$.

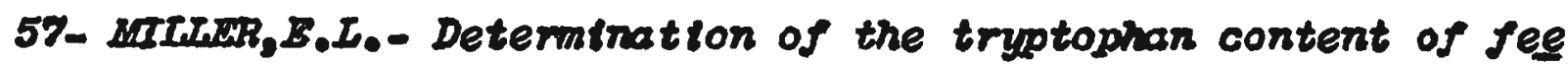
dingstups with particular reference to cereals a Inct PC. Agrtce, Iondon, $18(9) / 381-386,296 \%$.

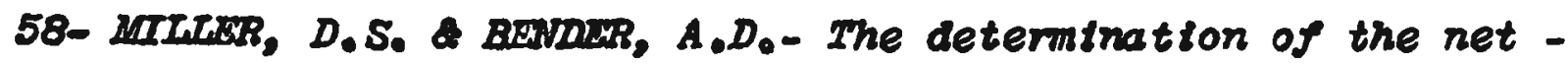
utilization of proteins by a shortened method. Bresuntro London, $g(4)$ \& 388-388, 2955 .

59- MORRISQN,A.B.- Mactors influencing the mutrittonal value of fish flour.III. Further studtes on avallability of amino

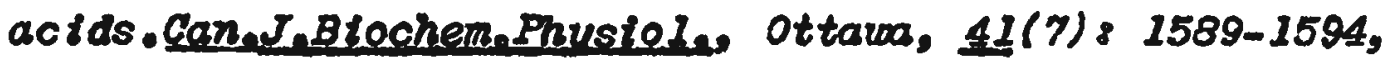
2963.

60- MORRISON, $A_{0} B_{0}$ - The inviuence of solvent extraction on the mu tritive walue of $f\left(s h\right.$ proteins.InsERW, $E_{0}$ KREUZER, $R_{0}\left(e d_{1}\right)$ Iish in rutrition, London, Fishing News (Books)Ltd, 1962。 p.201-206.

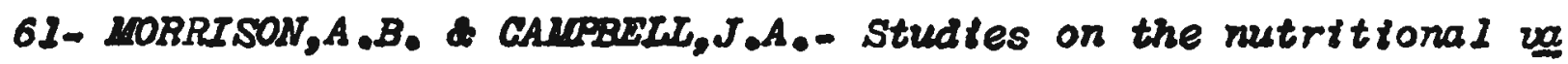
Ine of defatted fish flour. Cann.BtochemePhysio 1, Ottawor, $38(5): 467-473,1960$.

62. MORRISON,A,B, \& MaIAUGAIAN, J, $\mathcal{H}_{0}$ - VartablItty in nutritional

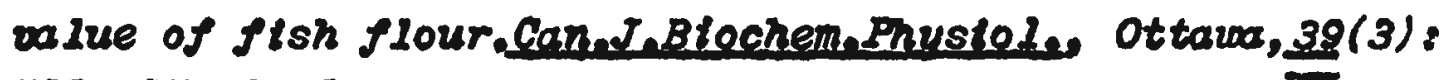
$511-517,1961$. 
63- MORRISON,A.B. LURNO,I.CO- Pactors tinfluencing the nutritio nal value of fish flour.IV.Reaction between 1.2-dichloroe thane and protein.CaneJeBlochems, Ottawa, 4ig(1):33-40, 1965.

64- INORRISON,A,BO \& SABRY, Z, I0- Pactors influencing the nutritio nal value of fish flour.II. A vallabiltty of lysine and sulfur amino actds.Can.JeBlochem,Phustole, Ottaw, 41 (3), 649-655, 1963。

65- 10RRISON,A.B. et altt - Factors influencing the nutrittonal walue of $f$ tsh flour.I.Iffects of extraction with chloroform or ethylen dtohlortde. JeNutr,Baltimore, $27(1): 97$ 104, 1962。

66- MUHWRR, $J_{0} C_{0}$ \& STOOKSY, $G_{0} K_{0}-$ Metabolic avellabiltty of fluort de from oyster shells, Jedent,Rese, Balt tmore, 39(4):858, 1960.

67- LURNO, $I_{0} C_{0}$ LORRISON,A.B. - Pactors influencing the nutritio nal value of fish flouriv-chlorocholtne chlortde, a toxic material in samples exctracted with 1,2-dtchloroethane, Can.J.Blochem, Ottawa, 45(7): 1049-1053, 1967。

68- NURNO, I. CO INRRISON, $A_{0} B_{0}$ - TOxtclty of 1,2-dichloroethane exctracted stsh protein concentrate. Can JeBlochem, Ottawa, 45(11) \& 1779-1781, 196\%。

69- MORRA $Y_{9} M_{0} M_{0}$ \& WILSON, $D_{0} C_{0}$ - FIuorine and nutrition in Norocco。 Dental studies in relation to environment.Bredent, $J_{\text {, }}$ London, $84(5): 97-100,2948$.

70- NATIONAL ACADEMT OF SCIENCE-NATIONAL RESEARCH COUNCIL, FOOD AND NUTRITION BOARD-Reccomended dietaTy allowance. 7 tho Rev.Ed.Publication, 1964, Washington D.C., 1968, 101poA pud Pluertde Abstract $1966 / 68$, Sect.4, Abst.160.

71- NIZEL, $A_{0} E_{0}$ et aldt - The effect of feeding fish protetn con centrate (PPC) in different amounts on cartes developement in rats. INTERRATIONAL ASSOCIATION DENTAL RESEARCH. 47 th. 
General Meeting, Houston, march, 1969-Proamm ard abstracts at papers. Chtcago, 1969, p.65, abstr.97.

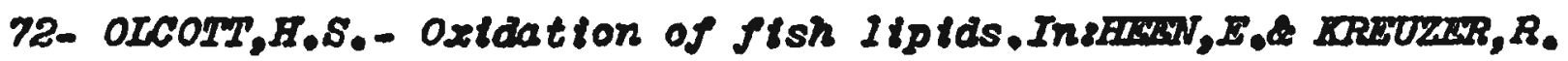
(ed.) Irtsh in mitrition. London, Fishing New (Books) Ita. 1962, $0.112-116$.

73- OLIVEIRA, $J_{0} N_{0}$ - OItgoelementos em fartnhas de milho e de peixe. An,Pze, Farado Pôrto, 15:5-31, 1955.

74- OPUSZIVSKA, To- Badanta nad Rola mazki myines w proftlaktyce prochntcy Zebow u Btalych Szczurow. Rocznikt Panstwowego zakloris Fion Warszawa, I7(3): 289-295, 1966 。

75- PETERS, CoFo- A fixagão de fińor de lambarls (Astyanax-tmacuLates e fascinateus). Seu efelto sobre a solubilidade, em ácido do esmalte dental de ratos brancos. (Rattres norvegicus, varalbinis, Rodentia, Nammalta) Pinactcaba, 1969,60p. |rese|

76- POURCHIS-CAMPOS, $M_{0} A_{0}$ - A twats conhectmentos sôbre o metabolis-

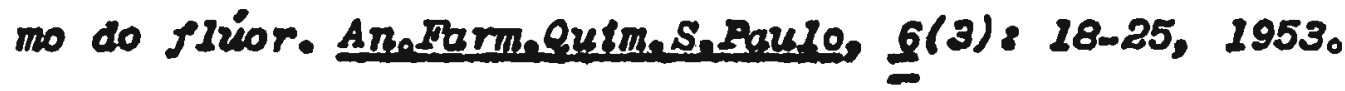

77- POURCHLY-CAMPOS, $M_{0} A_{0}$ - Contrtbutgão pa ra o estudo da flragão

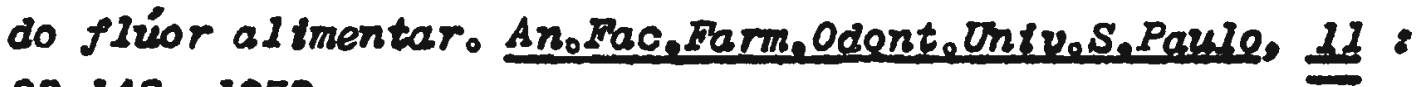
93-148, 1953。

78- POWLR, $E_{0} E_{0}$ - Characteristics and mutritional value of various fish protein concentrates. J,Fish,Res,Bd,Can, Ottawa, II (6) \&1489-1504, 1964。

79- POHER, $H_{0} E_{0}$ - An improved method for the preparation of $f$ ish protein concentrate from codaL.PishoRes,Bd.Can.s Ottawa, 19(6):1039-1045, 1962。

80- PRETORIUS, $P_{0} J_{0}$ MLERISTER, $A_{0} S_{0}-$ An aseessment of nutrit $t$ ve value of fish flour in the treatment of convalescent hass hiorior patients. AmaJeclinenutres New York, 14(3) 147 156, 1964。 


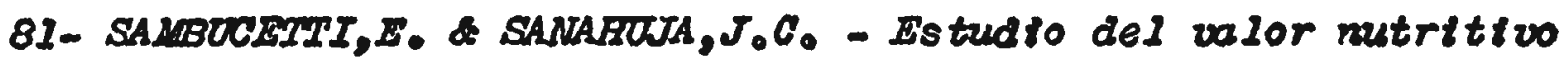
de los concentrados protelcos de ortgen antmal (hartina. de pescado) Ins Congresso Ponamerteano de Fanmicta e Bloqutmica, Buenos Atres, 1966 |Abstract|

82- STO PAOLO-INSTITOTO ADOLFO LUTZ-NO mas analfticas do Instituto Ado 1fo Iutz-V.I Métodos oufmicos e fĺstcos para análise de altmentos, Săo Paulo, p.28.

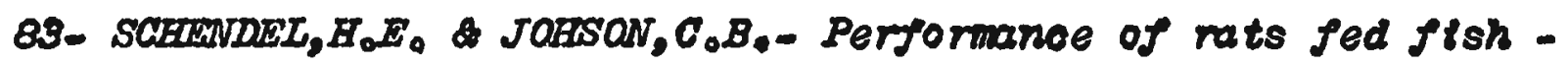
flour or casein as the sole source of dietary protein through four generations adulutra, Baltimore, g8(4) 845\%-460, 1968.

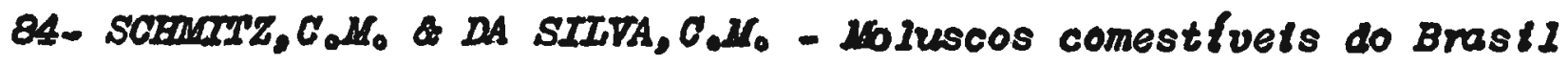
Teor de fiúor em mextlhões, berbigôes e sururu. An marm. QutmoS.Pau10, 11 (11/12): 163-166, 1960 。

85- SKAPIRO, $M_{0}$ et alti - Benefictal effects of gtsh protein concentrate on the bones and teeth of rats fed a rachitogentc diet。 INIERRATIONAL ASSOCIATION DENTAL RESKARCH.47th。 General Heeting, Houston, march. 1969 -Proanam and abstracts of papers. Chicago, 2969, p.65, abstr. 98.

86- SHURPALERAR, S.R. et alti - The effect of a supplementary pro tein food containing fish flour (from oll ardine) on the metabolism of nitrogen, calctum and phosphorus in children. Indian J.Peditat, Mysore, 30(187) \& 272-275, 1963.

87- SHURPALKKCAR, $S_{0} R_{0}$ et alti - Supplementary value of proteins of fish flour to those of groundnut flour and protein efficent ratto of a protein food containing groundnut, bengalgram and

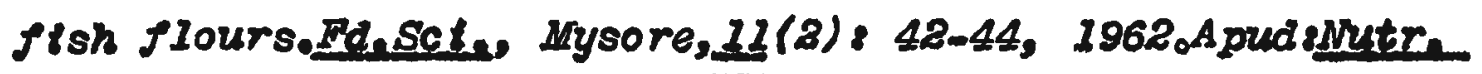
Abstrakeva, Aberdeen, 33(1):71-Abs.515, 1963。

88- SOGNAES, $R_{0} F H_{0}-A$ condition suggestive of threshold dental flue rosts observed in Iristan da Cunha.I.Clinical condtion of the teeth.J.dent,Res, Baltimore,20(4) 8303-313, 1941. 
89- SOGNAES, $R_{0} F_{0}$ A ARASIRENG, $W_{0} D_{0}$ - A condition suggestive of thres hold dental fluorosts observed in Tristan da Cunha IIoluom rine content of the teeth. Jedent,Res, Baltimore, 20(4) \& 315-322, 1941.

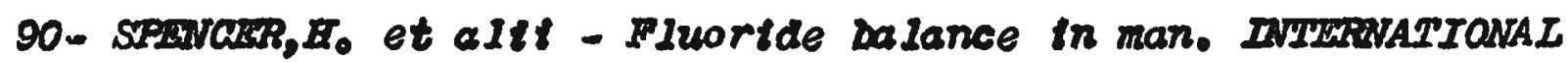
ASSOCLATION DENTAL RESEARCH, 46 th.General Neeting,Houston, march. 1968- Proaram and abstracts of papers, Chtcago, 1968, p.65, abstr. 279 .

91- SPEWWGBZ, $B_{0}$ o01.- Dttlization of fioh protein concentrate in man. Fed Proce 27(2): Abstro 1169, 2968。

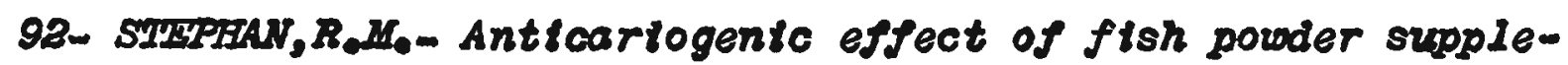
ments in expertmental diets fed to rats. INIJWRVATIONAL ASSO CIATION DENTAL RESERARCH. 47 thoGeneral Heeting, Houston, march, 1969- Program and abstracts of papers. Chicago, 1969, p.65, abstr. 100.

93-SIYZPIAN, $R_{0} M_{0}-$ Effect of ftsh and mtlk powders versus sugars on cartes in rats. INTERRATIONAAL ASSOCIATION DENTAL RESEARCH. 46 th. General Weeting, Houston, 1968-Proqram and abstracts of papers. Chicago, 1968, p.65, abstr. 365.

94- STILIINGS, B.R. et altt - Sequence of Itmiting amino actds in fish protein concentrate produced by isopropyl acohol extraction of red hake (Uxophucts chuss). Jolintre, Baltimore, 97(1): 70-78, 1969.

95- STOaSST, G, $K_{0}$ et alti - Further studies on fluoride absorptionProcesoc. ExpeBtoleNedes NoFork, 115: 295-298, 1964。

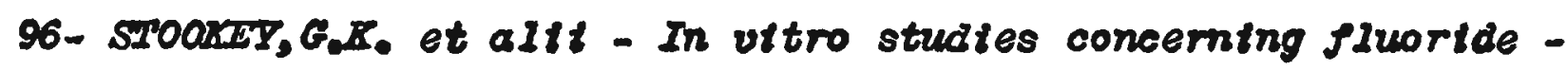
absorption. ProcosocenxpeBtedeMed, New York, 115:278-301, 2964。

97- SuRs, B.- The addition of small anounts of defatted fish flour to whole yellow com, whole wheat, whole and $m$ tlled rye grain sorginem and millet. I. Ins luence on growth and protein effictency. If Aretrtitie value of mineral in fish flour. $J_{0}$ Nutr, BaItimore, 63 (4):409-416, $195 \%$. 
98- U.S.DEPARTMENT OF HEALTH EDOCATION AND WELFARE.FPOd and Drug Administration. Rules and regulations, \$121.1202sunole ftsh protein concentrate. PedoRean Wrashington, D.C. $32(22):$ 1174, $296 \%$.

99- U.S.DEPT OF TEEE INITERIOR PISAR AND WILDLIFE SERVICT. BureaU of Comerctal Ptsheries Marthe protein concentrate. Wasnington, 1966, 26 po |Fishery Leaflet, 584|

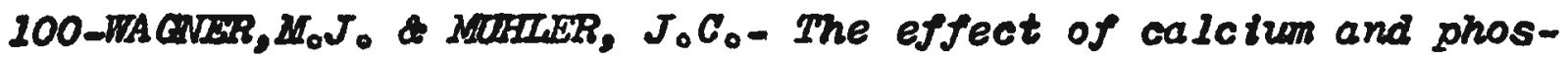
phorus on fluortde absorption. Jedent,Res, Baltimore, 39 (1) 8 49-52, 1960 。

101-HALDBOTT, $G_{0} L_{0}$ - Perspeotives in mutritionoPluortde in foodoAmo Jelinelutres New York, 12(6): 455-462, 1963.

102-TANIEZ,E。 DarOSO,Go- Hartna de pescado, aspectos btológtcos technológtcos y economicos. Nutrictón Bromatol Toxicole, Sant togo de Chtle, $3(2)$ : 43-62, 1964 .

203-TAREZ, $I_{0}$ et alti - The ftsh protetn concentrate story.6.Quin tero fish protein concentrates protein quality and use in foods. Fd.Technole, Champatgn, 21 (12): 1604-1610, 1967.

I04-ZIPKIN, $I_{0}$ \& MaLURE, $F_{0} J_{0}=$ Deposttion of fluorine in the bones and teeth of the growing rat, Juntre, Baltimore, $47(4)$ s $611-620,1952$.

105-ZIFKIV, I. et altt - The btologtcal avatlability of the fluorl de of $f$ ish protein concentrate (F.P.C.) in the rato-No pre 10 |commicação pessoall

106-2IFKIN, $I_{0}$ et altt - Deposttion of fluortde, calctum and phosphorus in expertmental-10w phospinorus rikets. Jevitra, BaI timore, 67(1): 59-67, 1959 .

107-ZUCAS, S.M. \& IAJOLO, $F_{0} M_{0}$ - Frasco de difusão para o tsolamen to de pequenas quantidades de flior-ReveFace FarmeBtoqutm. 
S.Paute, $6(1): 33-34,1968$.

108-ZUCAS, S.MO et allt - Galola metabólica para ratos ensalada com ${ }^{65}$ in lenvtado para publicacãol 